Article

\title{
Injection and Combustion Analysis of Pure Rapeseed Oil Methyl Ester (RME) in a Pump-Line-Nozzle Fuel Injection System
}

\author{
Flavio Caresana $^{1}\left(\mathbb{D}\right.$, Marco Bietresato $^{2} \mathbb{D}$ and Massimiliano Renzi ${ }^{2, *(D)}$ \\ 1 Dipartimento di Ingegneria Industriale e Scienze Matematiche, Università Politecnica delle Marche, \\ I-60131 Ancona, Italy; f.caresana@univpm.it \\ 2 Facoltà di Scienze e Tecnologie, Libera Università di Bolzano, I-39100 Bolzano, Italy; \\ marco.bietresato@unibz.it \\ * Correspondence: massimiliano.renzi@unibz.it; Tel.: +39-0471-0171816; Fax: +39-0471-017009
}

Citation: Caresana, F.; Bietresato, M.; Renzi, M. Injection and Combustion Analysis of Pure Rapeseed Oil Methyl Ester (RME) in a Pump-Line-Nozzle Fuel Injection System. Energies 2021, 14, 7535. https://doi.org/10.3390/ en14227535

Academic Editor: Rocio Maceiras

Received: 27 September 2021

Accepted: 8 November 2021

Published: 11 November 2021

Publisher's Note: MDPI stays neutral with regard to jurisdictional claims in published maps and institutional affiliations.

Copyright: (c) 2021 by the authors. Licensee MDPI, Basel, Switzerland. This article is an open access article distributed under the terms and conditions of the Creative Commons Attribution (CC BY) license (https:// creativecommons.org/licenses/by/ $4.0 /)$.

\begin{abstract}
This work suggests an interpretation to the quantitatively higher formation of $\mathrm{NO}_{\mathrm{x}}$ in a compression ignition (CI) engine when fueled with pure biodiesel (B100). A comparative study about the use of rapeseed oil methyl ester (RME) and diesel fuel mixtures on injection timing, in-chamber pressure, heat release rate, and $\mathrm{NO}_{\mathrm{x}}$ emissions were carried out using a diesel engine equipped with a pump-line-nozzle injection system. Such engines are still widely adopted mainly in agriculture, as the fleet of agricultural machinery is particularly old (often over 20 years) and the use of biofuels can reduce the environmental footprint of the sector. This work aims to supply some general explanations and figures useful to interpret the phenomena occurring within the fuel line and in the combustion process when using biodiesel, as well as in engines with different construction characteristics and fueling systems. Given the contradictory results available in the literature, the so-called "biodiesel $\mathrm{NO}_{\mathrm{x}}$ effect" cannot be explained solely by the different physical properties of biodiesel (in particular, a higher bulk modulus). Experimental results show that, with the same pump settings, the start of injection with the RME is slightly advanced while the injection pressure values remain almost the same. With the RME, the pressure in the injection line increases faster due to its greater bulk modulus but the pressure rise starts from a lower residual pressure. The start of combustion takes place earlier, the heat release during the premixed phase is steeper, and a higher peak is reached. The $\mathrm{NO}_{x}$ emissions with the RME are at least $9 \%$ higher when compared to mineral diesel fuel. The greater amount of the RME injected per cycle compensates for its minor lower heating value, and the brake torque at full load is similar to the two analyzed fuels. Finally, a variation of the pump line timing is evaluated in order to assess the effect of the delay and the advance of the injection on the performance of the engine and on the emissions. A viable and simple solution in the variation of the injection strategy is suggested to counterbalance the biodiesel $\mathrm{NO}_{\mathrm{x}}$ effect.
\end{abstract}

Keywords: compression ignition engine; biodiesel; B100; heat release rate; injection timing advance; injection pressure; biodiesel $\mathrm{NO}_{x}$ effect

\section{Introduction}

The role of "alternative" fuels to meet the reduction targets in the impact of the energy production and transport sectors has increased in the last few years. Currently, "bioenergy" is the largest contributor to the global renewable energy supply, especially for thermal energy production, but has not yet reached a large-scale production for liquid biofuels, as this must overcome some complex research uncertainties on the management of those resources, their lifecycle emissions, their effects on water, the soil management, the process efficiencies, as well as facing their potential negative effects [1]. In particular, among the biomass-derived fuels, and despite the existence of some serious problems associated with their application with respect to feedstock requirements and land availability — the "food 
vs. fuel" debate-the so-called "first generation biofuels" have grown mainly thanks to government subsidies and legislative pressures [2].

Meanwhile, novel biofuels have been introduced that use nonfood biomass, dedicated energy crops, and biomass coproducts and waste from many different sectors, such as agriculture, horticulture, forestry, paper and pulp processing, and wastes (e.g., municipal solid waste (MSW)) [3]. Novel improved technologies are being developed to increase the production yield of qualitatively acceptable biodiesel [4], and new processes have been proposed to improve the low-temperature performance of biodiesels [5-7].

Among the available biofuels, "biodiesel" is one of the candidates in this class and its use is expanding throughout the world [8]. As an example, total biofuel consumption in the EU was around 17.0 Mtoe in 2018, and in terms of energy content, while biodiesel's share was $82.0 \%$, bioethanol was $17.1 \%$, and biomethane fuel was $0.9 \%$, respectively [9]. The main advantage of the use of biodiesel resides in its renewability, which allows for the reduction of the burdens of greenhouse gases (GHG). From the environmental point of view, it is possible to enumerate other important benefits deriving from the chemical composition of biodiesel, which has a minimal sulfur and aromatic content. Other properties, compared to mineral diesel, include a higher cetane number, lubricity, and flash point, while the toxicity is reduced. Among the detrimental characteristics, it is possible to list its lower volatility, the calorific value, the oxidation stability [10,11], and the higher viscosity [12] and pour point [13] that, however, can be adjusted due to new processes that improve the low temperature performance of biodiesels [5-7]. When the biodiesel is blended with diesel fuel at high percentages, it can also cause reliability problems for the engine components, as it can cause corrosion and chemically attack some plastic components of seals and coatings [14].

Different oils are used to produce biodiesel fuels depending on the local availability. The most common in the United States is soybean oil (from Glycine max (L.) Merr.); coconut oil (from Cocos nucifera L.) and palm oils (mainly from Elaeis guineensis Jacq.) are used in Malaysia and Indonesia; the Jatropha (Jatropha curcas L.), Karanja (Pongamia pinnata L.), and Mahua trees (Mahua Indica J. F. Gmel) are used as a significant fuel sources in India and southeast Asia; while rapeseed oil-based esters (from Brassica napus L.) are commonly used in many European countries $[15,16]$. In Austria and Germany, neat biodiesel is widely used, whereas in France, Italy, Spain, Sweden, the Czech Republic, and other European countries, fuel blends of diesel fuel with up to $25-30 \%$ rapeseed oil methyl ester (RME) are popular [17]. Some reviews on the effects of biodiesel fuels on compression-ignited (CI) engine performance and emissions report the following main outcomes [18-22]: (i) the fuel consumption increases proportionally to the loss of the heating value of the fuel; (ii) the particulate matter (PM) emissions show a consistent reduction; (iii) a minimal or absent loss of power is reported, except when maximum power is required. As regards the brake thermal efficiency (BTE), its value is not significantly affected with biodiesel, but a slight increase or a reduction in the BTE can be noted depending on the engine load, the type of biodiesel, and the blend with mineral diesel fuel [23]. Improvements in the efficiency are mainly due to the synergic blending effects that could be caused by the reductions in friction losses [24]; instead, lower efficiencies are typically reported at high engine loads and rotational speeds because of the poor spray characteristics, poor mixing, high viscosity, and the lower calorific value of biodiesel [25]. As regards the emissions, all of the authors agree in the reduction of the carbon monoxide (CO), hydrocarbon (HC), and PM emissions due the use of biodiesel [26]. With regard to the nitrogen oxides $\left(\mathrm{NO}_{\mathrm{x}}\right)$ concentration, most of the authors [11,14] report a slight increase with biodiesel; nevertheless, some studies have actually found very different evidence, spanning from "NO $\mathrm{NO}_{\mathrm{x}}$ increment only in some operating conditions" up to "there is lack of difference between diesel fuel and biodiesel" or even "NO emissions decrease with biodiesel". As it appears from the literature reviews [27-30], despite the great number of research articles available, various topics regarding biodiesel use in diesel engines remain unsolved and need further investigation. In 2007, Lapuerta et al. [27] showed that, although a dominant 
trend could be found in most cases, there are always opposing trends proposed elsewhere by contrast. As possible reasons for this, they indicate: the large number of different engine technologies tested, the various operating conditions or driving cycles followed, the different biodiesel fuels used (i.e., obtained from different feedstocks and with different qualities), and the various measurement techniques and procedures applied. In 2018, Chen et al. [31] titled their article " $\mathrm{NO}_{x}$ emission of biodiesel compared to diesel: Higher or lower?", thus evidencing that the question has remained open. On a deeper analysis, the need for further research appears less surprising, as the literature on the subject consists only of results obtained from different engines, with different injection systems, and in different operating conditions. Moreover, the effect of biodiesel is sometimes addressed by taking the engine as a "black box"; thus, not all the data necessary to analyze the problem are reported (or known by the experimenters). Moreover, in several experiments, it is very complex to isolate the different thermo-chemical phenomena and to control the operating conditions and devices of the engine that can contribute to the variation of the performance and the emissions of a motor fueled with blends of biodiesel.

In general, the main causes of the increase in the $\mathrm{NO}_{x}$ formation are [29]: (i) the advancement of the injection (due to the higher bulk modulus of biodiesel) and, therefore, the higher in-cylinder pressure and temperature; (ii) the lower formation of soot and the consequent lower radiative heat transfer, which implies a higher combustion temperature; (iii) the higher oxygen content in the biodiesel composition, which facilitates the combustion and the formation of $\mathrm{NO}_{x}$; (iv) other physical properties of the fuel, like the different viscosity and density, which increase the amount of fuel injected with a consequent higher combustion temperature, lower spray cone angle, and fuel atomization; (v) the higher and advanced heat release rate (HRR) in the premixed phase of the combustion process. The various combinations of the factors cited above interfere with each other to determine $\mathrm{NO}_{\mathrm{x}}$ emissions: the increasing or decreasing trend depends on the delicate balance due to every change in the fuel and combustion characteristics or engine operating conditions [22].

However, it is worthwhile to note that there is no shared agreement on the reasons for the higher $\mathrm{NO}_{\mathrm{x}}$ formation with biodiesel. At first this could seem quite strange, given the number of researchers that have analyzed the effects of these parameters, starting from the first organized studies by the National Renewable Energy Laboratory (NREL) to measure the sound speed of biodiesel and to establish its impact on the injection timing in diesel engines [32]. In their review article, Jinlin Xue et al. [28], in trying to individuate the factors of effect on $\mathrm{NO}_{x}$ emissions for biodiesel, indicate the higher oxygen content as the main cause of the $\mathrm{NO}_{x}$ emissions increase, but they say that the injection characteristics also have an impact and that a further study is needed to inquire into the effect of the injection timing and pressure. A key role of fuel-based oxygen was also found by Graboski and McCormick [33] after analyzing a large number of test results of various vegetable oil based fuels. They concluded that the main advantage of feeding biodiesels in diesel engines seemed related to their high oxygen content. On the other hand, Lapuerta [34] suggests that the oxygen/fuel mass ratio of biodiesel (equal to 2.92) is lower than the mineral diesel fuel ratio (3.58) and, therefore, the oxygen content cannot be the reason for the higher concentration of $\mathrm{NO}_{x}$.

Among the different types of biodiesels and fueling systems, this study focuses on a methyl ester biodiesel used in a pump-line-nozzle (PLN) injection system. The PNL CI engines are still a widespread technology in small-scale engines for cogeneration, for industrial applications, in the agricultural sector, and in off-highway diesel engine applications where more advanced technologies are too expensive and, often, advanced gas-cleaning solutions cannot be adopted. Indeed, in all of these machines, a simple and straightforward solution for the reduction of pollutants and the limitation of greenhouse gas emissions is surely the adoption of alternative (bio)fuels [35]. The engine used here is also particularly representative of the majority of the engines used in agricultural vehicles, and also due to a mere numerical issue: in the most developed countries, the agricultural sector is characterized by a very low turnover of mechanical units (e.g., even less than 
$1 \%$ in Italy in 2012 [36]) and a consequent high average age (around 25 years in Italy [36]), while developing countries prefer engines/machines with a simple and robust construction due to many economic and environmental conditions. In both scenarios, newer engine technologies (e.g., the common rail) are still struggling to gain market shares. The simplicity of these engines also has a further appreciable effect in an experimental context: due to their intrinsic simplicity, it is possible to avoid any masking of the effects of fuel substitution as a result of the engine's automatic adjustment mechanisms used in more recent, electronically controlled engines (first and foremost, the automatic injection advance variation system).

Diesel engines operating on neat methyl esters (ME) or their blends with diesel fuel have already been tested by various researchers evidencing, in line with the majority of the biodiesels, reductions in $\mathrm{CO}, \mathrm{HC}$, and $\mathrm{PM}$ emissions and smoke, along with a higher concentration of $\mathrm{NO}_{x}$ in the exhausts. Çelikten [37] reported that in all performance modes, RME leads to lower $\mathrm{CO}$ and to higher $\mathrm{NO}_{x}$ emissions than the fossil fuels. Krahl et al. [38] found similar results on these pollutants, but they could not find a general tendency regarding the $\mathrm{HC}$ emissions. Most of the authors agreed that the reduction of the calorific value due to the ME mixing with diesel fuel causes an increase in the brake-specific fuel consumption (BSFC) [39-43]. Some authors have reported that full load torque in unchanged diesel engines does not vary substantially by switching from diesel fuel to the ME biofuels because the actual energy content delivered per each active stroke of the plunger is not substantially lower than with the diesel fuel [44,45]. Indeed, the higher viscosity of the RME reduces the internal leakages of the injection pump, and this increases the volumetric fuel delivery per stroke. For example, Labeckas et al. [39] found that, within an unmodified diesel engine, the volumetric fuel delivery per stroke with the RME increased by about $2.6 \%$ with respect to the diesel fuel.

As far as the injection pressure and an advance in the start of ignition (SOI) is considered, it is necessary to assess in a different way the engines that operate with a common rail system and with a mechanical injection system. In particular, in the mechanical injection systems, the injection timing can be modified only by regulating the fuel compression stroke with some shims. An advanced injection timing leads to enhancements in the turbulence of the mixture, to an earlier and rapid combustion, to a longer ignition delay time, and to higher combustion chamber pressures and temperatures [30,46]. On the other hand, a retarded injection timing results in lower chamber pressures and temperatures during the combustion, as well as in a shorter ignition delay time [30]. Several experimental investigations $[22,30]$ have revealed that an advance of the injection timing results in a reduction of $\mathrm{CO}$, unburned $\mathrm{HC}$, and PM emissions. The same studies showed that retarding the fuel injection can reduce the $\mathrm{NO}_{x}$ concentration at the exhaust thanks to the reduction of the peak temperature in the engine [47]. As a matter of fact, both the injection timing and the injection pressure are easily controllable only in common rail injection systems, where the SOI event is commanded by the electronic control unit (ECU) and the injection pressure in the rail can be easily regulated. For common rails, one could reasonably conclude that the injection timing is fluid-independent, whilst the pressure in the rail may vary with biodiesel in case the same torque has to be reached [48-50]. Nevertheless, an advance in the SOI and a higher in-cylinder pressure was also reported in common rail engines [51]. However, mechanical injection systems have been shown to be influenced by some fluid properties, mainly the bulk modulus and the viscosity, and it is almost generally accepted that, when substituting biodiesel to diesel fuel: (i) the SOI is advanced and (ii) the injection pressure becomes higher. These conclusions are somehow taken for granted and often used to explain the biodiesel $\mathrm{NO}_{\mathrm{x}}$ effect, and their combined effect advances the start of combustion (SOC) and contributes to a higher combustion rate; both enhance the $\mathrm{NO}_{\mathrm{x}}$ formation according to the well-documented Zeldovich mechanism [52]. It is worth remembering that only data from experiments at the fixed position of the injection pump should be considered. If the engine was set at the same torque level (for a given rotational speed), a greater amount of biodiesel should be injected to compensate for its lower heating value. In such cases, the injection pump settings should not be the same for the diesel fuel and the 
biodiesel. Moreover, some injection pumps have a fixed end of injection timing and, when additional quantities of fuel are requested to be injected, the start of injection is advanced.

In a previous article [53], the differences in the injection timing and the pressure of the RME as an alternative to diesel fuel in a PLN injection system were discussed. The final considerations suggested that the injection timing due to the higher bulk modulus of biodiesel is less advanced than is commonly believed.

The aim of the present work is to study in greater detail the injection characteristics of a CI engine fueled with pure RME (B100) in pump-line-nozzle systems. In such engines, the adoption of modern injection solutions and gas cleaning solutions is necessarily limited due to cost issues, and a lower environmental impact can only be obtained by using alternative (bio)fuels and tuning their management so to optimize the performance and the emissions. This study tries to supply some general explanations and figures that can be helpful to interpret the phenomena occurring in the fuel line and in the combustion process when using biodiesel, as well as in engines with different construction characteristics and fueling systems. Specifically, the performance variations, the thermal efficiency, and the $\mathrm{NO}_{\mathrm{x}}$ concentration in a mechanical PLN engine are reported in this work. Further analyses and the consequences on combustion behavior are evidenced, in particular the SOI and the SOC advances are shown, and the trend of the HRR is evaluated with the aim of finding a correlation with the biodiesel, etc. Moreover, a quick and simple modification of the fuel injection timing on the pump line was tested in order to highlight the chance of reducing the $\mathrm{NO}_{\mathrm{x}}$ increase in this typology of engines without causing any performance decay. Some authors also delved into the RME combustion characteristics [54-61], and their results are addressed in the concluding Section 3.4 and compared with those of the present study.

\section{Materials and Methods}

The experiments were carried out on a single-cylinder Ruggerini RF91 diesel engine (by Kohler Lombardini, Reggio nell'Emilia, Italy [62]), whose main characteristics are described in Table 1. The engine was tested on an APIcom RE100 test stand (Cento, Ferrara, Italy) with commercial diesel fuel and rapeseed biodiesel (Figure 1). At the end of each trial, the fuel was switched back to diesel fuel and the engine was kept running for a while before shut-down to flush out the biodiesel from the fuel line and the injection system. The properties of the two fuels are reported in Table 2. In particular, according to the EASAC report 2012 classification, the biodiesel used during the experiments is a first generation one, produced starting from the oil extracted from rapeseed and passed through refining, transesterification, and subsequent distillation processes [16].

Table 1. Technical characteristics of the tested diesel engine (Ruggerini RF51).

\begin{tabular}{cc}
\hline Quantity & Specification \\
\hline Type & Single-cylinder four-stroke direct injection \\
Nr. of valves & $2-\mathrm{OHV}$ \\
Bore $\times$ stroke & $90 \times 75 \mathrm{~mm}$ \\
Displacement & $477 \mathrm{~cm}^{3}$ \\
Compression ratio & 18.5 \\
Maximum power & $8.1 \mathrm{~kW}(11 \mathrm{CV})$ at $3600 \mathrm{rpm}$ \\
Maximum torque & $25 \mathrm{~N} \cdot \mathrm{m}(2.5 \mathrm{~kg} \cdot \mathrm{m})$ at $2500 \mathrm{rpm}$ \\
Injection advance & $16^{\circ} \mathrm{CA}$ before top dead center \\
Injection nozzle opening pressure & $210 \mathrm{bar}$ \\
\hline
\end{tabular}

In-cylinder and injection pressures were measured by using piezoelectric transducers, specifically an AVL GU12P (Graz, Austria [63]) fitted on the cylinder head, and a PCB Piezotronics 112A21 (Depew, NY, USA [64]) fitted on the injection pipe about $10 \mathrm{~mm}$ apart (Figure 2). An AVL 3066A0" charge amplifier received the outputs of the pressure transducers and fed them to an AVL 619 INDIMETER system. An AVL 36401 encoder, connected to the engine output shaft, passed its signal to the AVL 619 INDIMETER through 
an AVL $3064 Z 03$ light pulse converter. For each working condition, pressure signals were measured over 50 consecutive cycles with $0.5^{\circ}$ resolution, and then averaged. The main characteristics of the measuring instruments are reported in Table 3.

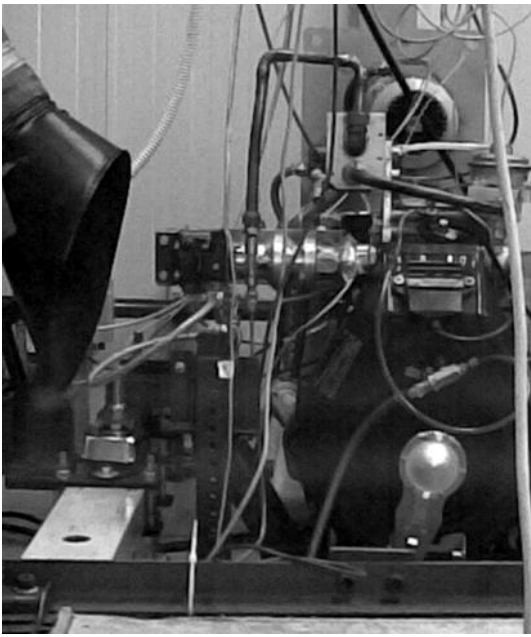

(a)

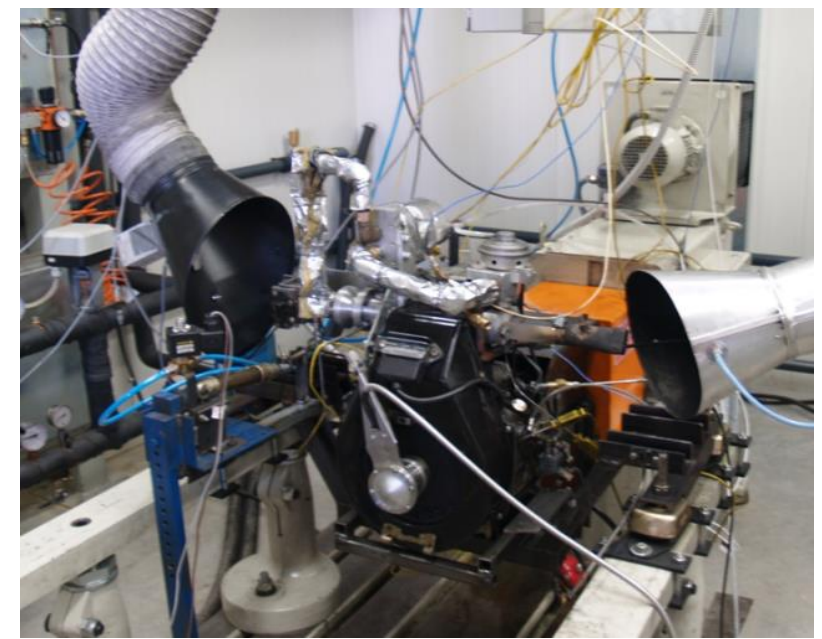

(b)

Figure 1. Frontal (a) and lateral (b) views of the Ruggerini RF51 engine installed at the APIcom RE100 test stand for the execution of the tests.

Table 2. Main specifications about the used fuels.

\begin{tabular}{cccc}
\hline Quantity & Unit & Diesel Fuel & Biodiesel \\
\hline Bulk modulus & $\mathrm{MPa}$ & 1490 & 1650 \\
Cetane number & - & 48 & 54 \\
$\mathrm{C} / \mathrm{H} / \mathrm{O}$ & $\mathrm{molar}$ ratio & $16: 30: 0$ & $19: 34: 2$ \\
Density at $15^{\circ} \mathrm{C}$ & $\mathrm{kg} \cdot \mathrm{dm}^{-3}$ & 0.835 & 0.885 \\
Lower heating value on a mass basis $\left(\mathrm{LHV}_{\mathrm{m}}\right)$ & $\mathrm{kJ} \cdot \mathrm{kg}^{-1}$ & 42,739 & 37,400 \\
Kinematic viscosity at $40^{\circ} \mathrm{C}$ & $\mathrm{mm}^{2} \cdot \mathrm{s}^{-1}$ & 2.60 & 4.50 \\
Carbon content & $\mathrm{wt} \%$ & 86.5 & 77.4 \\
Hydrogen content & $\mathrm{wt} \%$ & 13.4 & 12.0 \\
Oxygen content & $\mathrm{wt} \%$ & 0.0 & 10.5 \\
Sulfur content & $\mathrm{wt} \%$ & 0.05 & $<0.01$ \\
Stoichiometric air-fuel ratio & - & 14.5 & 12.6 \\
Iodine value & $\mathrm{g}\left(\mathrm{I}_{2}\right) \cdot(100 \mathrm{~g})-1$ & - & 118.2 \\
Pour point & ${ }^{\circ} \mathrm{C}$ & -26 & -12 \\
Flash point & ${ }^{\circ} \mathrm{C}$ & 72 & $>150$ \\
Biodegradability (after 28 days) & $\%$ & 18 & 85 \\
\hline
\end{tabular}

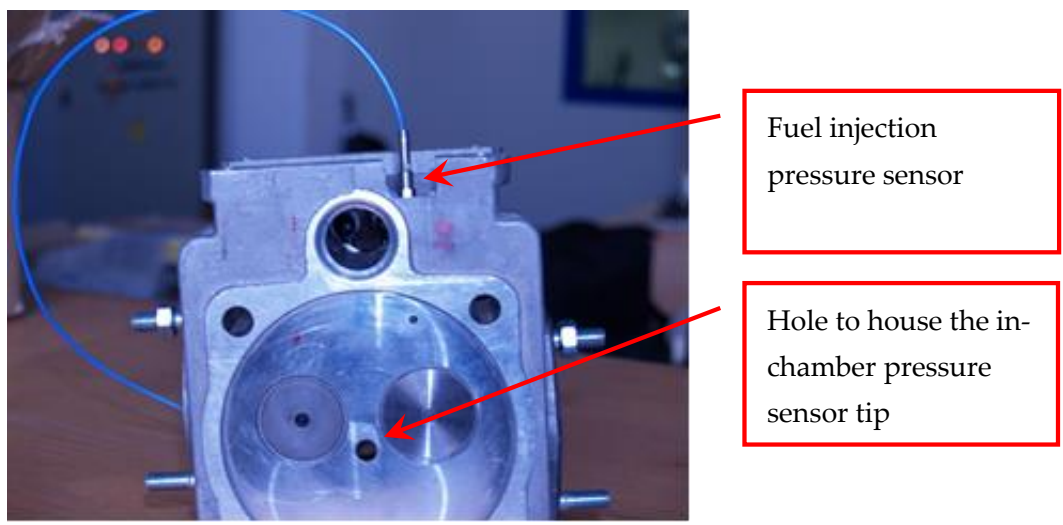

Figure 2. Detailed view showing the positions on the engine head of the piezoresistive sensors by AVL used to measure the pressure in the combustion chamber and in the fuel injection subsystem. 
Table 3. Main specifications about the measuring instruments used in the test campaign.

\begin{tabular}{cc}
\hline Instrument & Specifications \\
\hline Dyno brake model (APIcom, Cento (FE), Italy) & APIcom Eddy current RE100-X TWIN-4943/02 \\
Torque measurement (APIcom, Cento (FE), Italy) & Range 0-500 N·m; Uncertainty $\pm 0.25 \%$ \\
Rotational speed measurement (APIcom, Cento (FE), Italy) & Range 0-10,000 rpm; Uncertainty $\pm 10 \mathrm{rpm}$ \\
Load indicator (APIcom, Cento (FE), Italy) & Range 250-6000 W; Uncertainty $\pm 10 \mathrm{~W}$ \\
Temperature indicator & Range 0-900 ${ }^{\circ} \mathrm{C} ;$ Uncertainty $\pm 1^{\circ} \mathrm{C}$ \\
Fuel Volume & Burette range $1-30 \mathrm{~cm}^{3} ;$ Uncertainty $\pm 0.2 \mathrm{~cm}^{3}$ \\
Exhaust gas analyzer & Range NO 0-5000 ppm; Uncertainty $\pm 50 \mathrm{ppm}$ \\
Pressure transducer (AVL, Graz, Austria) & Range HC 0-20,000 ppm; Uncertainty $\pm 10 \mathrm{ppm}$ \\
Crank angle encoder (AVL, Graz, Austria) & Range CO 0-10\%; Uncertainty $\pm 0.03 \%$ \\
& Range 0-110 bar; Uncertainty $\pm 0.1 \mathrm{bar}$ \\
\end{tabular}

By using appropriate correlations for the heat losses, the gross HRR would have been derived from the net HRR (NHRR) curve but considering that the aim was comparing the combustion behavior of diesel fuel and B100 in the same engine, the differences in heat losses were considered to be the same in all the fueling conditions, thus not influencing the outcomes of the study. Besides, most of the literature regarding the analysis of RME combustion, in engines similar to that of the present study, report data on either the net or the apparent heat release rate.

The SOC was located in correspondence with the crank angle (CA) at which the first derivative of the in-cylinder pressure with respect to crank angle $(d p / d \theta)$ suddenly changes its slope, going from a negative to a positive value, and so presenting a local minimum [65].

During the experimental campaign, the engine was tested at full load and at rotational speeds spanning from $2000 \mathrm{rpm}$ to $3000 \mathrm{rpm}$, with steps of $250 \mathrm{rpm}$. The pump control rack was fixed at its maximum so that the pump operated in the same way independently of the delivered fuel. By doing so, only differences in the fuel properties were responsible for changes in the injection and combustion parameters. Besides, as shown in Section 3.1, the brake mean effective pressures (BMEPs) at full load were almost the same with the two fuels. For this reason, the full-load comparisons are also comparisons at nearly the same BMEP value.

\section{Results}

\subsection{Brake Torque, Fuel Consumption, and $N O_{x}$ Emissions}

Figure 3 shows the fuel mass flow rate and the corresponding injection quantities per cycle as a function of the rotational speed. The mass of B100 injected per cycle is $8-10 \%$ greater than that of the diesel fuel to compensate for the lower heating value. Consequently, the engine brake torque, as shown in Figure 4, is almost the same with the two fuels, while the BSFC of the RME is slightly higher, in accordance with the higher fuel flow rate injected. These results confirm the outcomes of other authors that studied similar injection systems $[44,45]$.

Figure 5 reports the comparison of $\mathrm{NO}_{x}$ emissions with the diesel fuel and the RME. The $\mathrm{NO}_{\mathrm{x}}$ concentrations are higher with the RME than with the diesel fuel, thus confirming the well-known biodiesel $\mathrm{NO}_{\mathrm{x}}$ effect, except for the higher rotational speeds, in correspondence to which the differences between the two fuels become lower. Figure 6 reports the percentage increase of the $\mathrm{NO}_{x}$ concentration in the exhaust with the RME compared to the diesel fuel as a function of the rotational speed. On the same chart, the variations of the heat release peak between the diesel fuel and the RME during the combustion process are also reported. Even though a detailed description of the combustion process is reported in the next section, this interesting figure is anticipated, as it helps to highlight how the increase of the $\mathrm{NO}_{\mathrm{x}}$ emissions with biodiesel is strongly correlated to the increase of the heat release peak; indeed, the two above-mentioned trends present a similar morphology. This can be explained by considering the main mechanism of $\mathrm{NO}_{\mathrm{x}}$ formation in a combustion process: 
the thermal formation mechanism. A higher peak in the heat release is obviously correlated to a higher local temperature and pressure in the combustion chamber, thus to a higher risk of formation of this polluting compound.

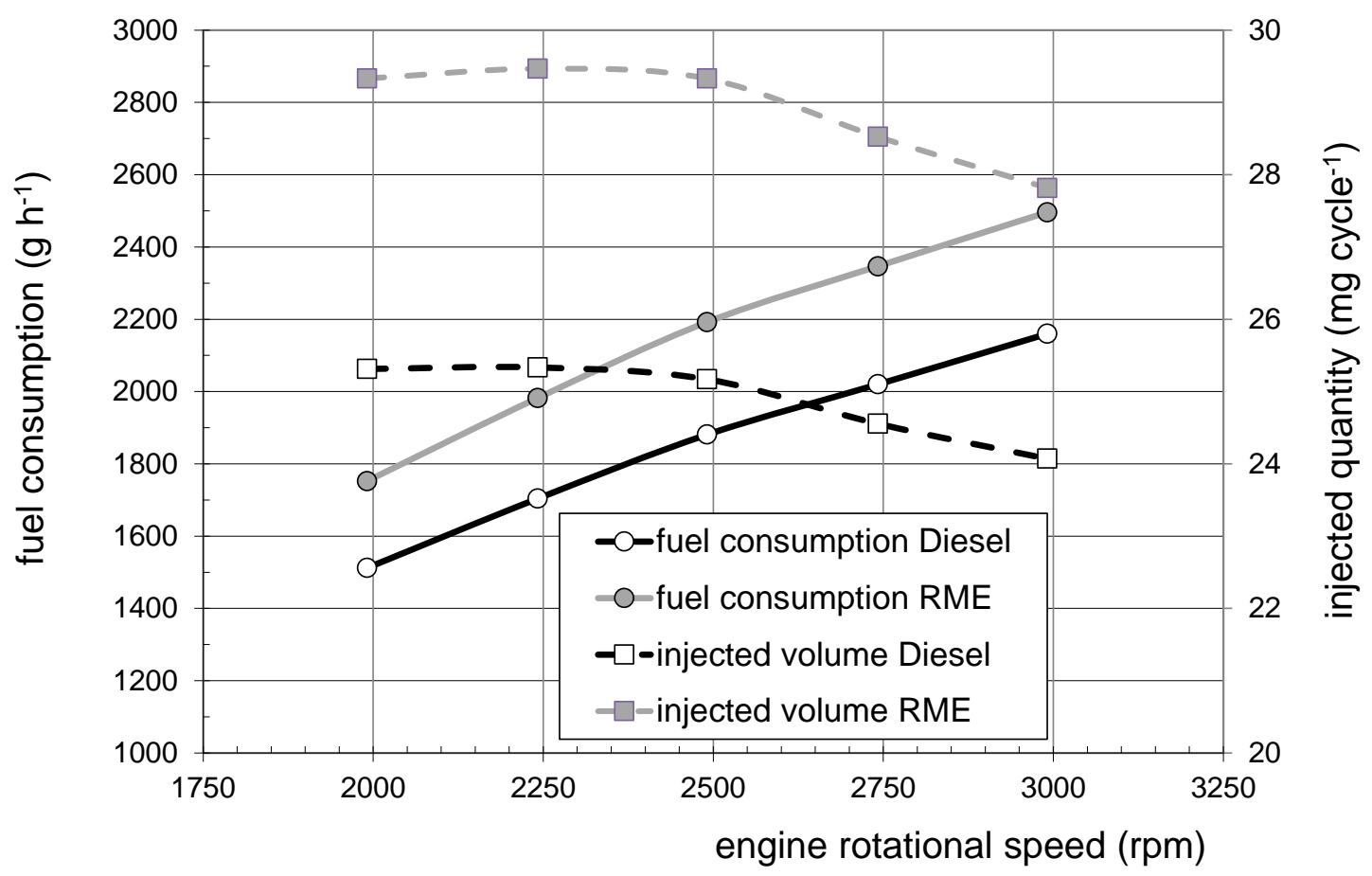

Figure 3. Fuel mass flow rate and injected mass per cycle as a function of the engine rotational speed for the two tested fuels.

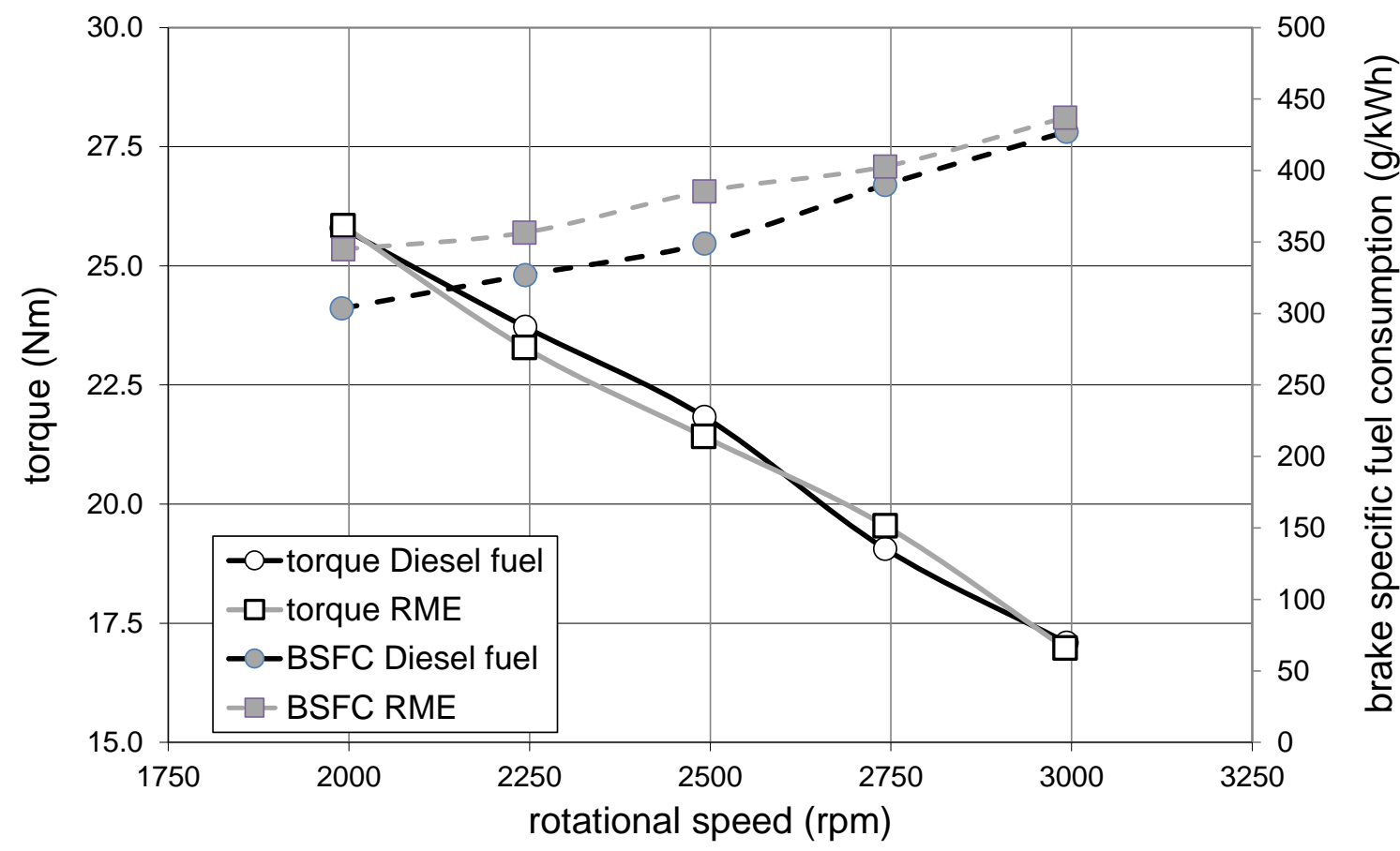

Figure 4. Engine torque and BSFC as a function of the rotational speed for the two tested fuels. 


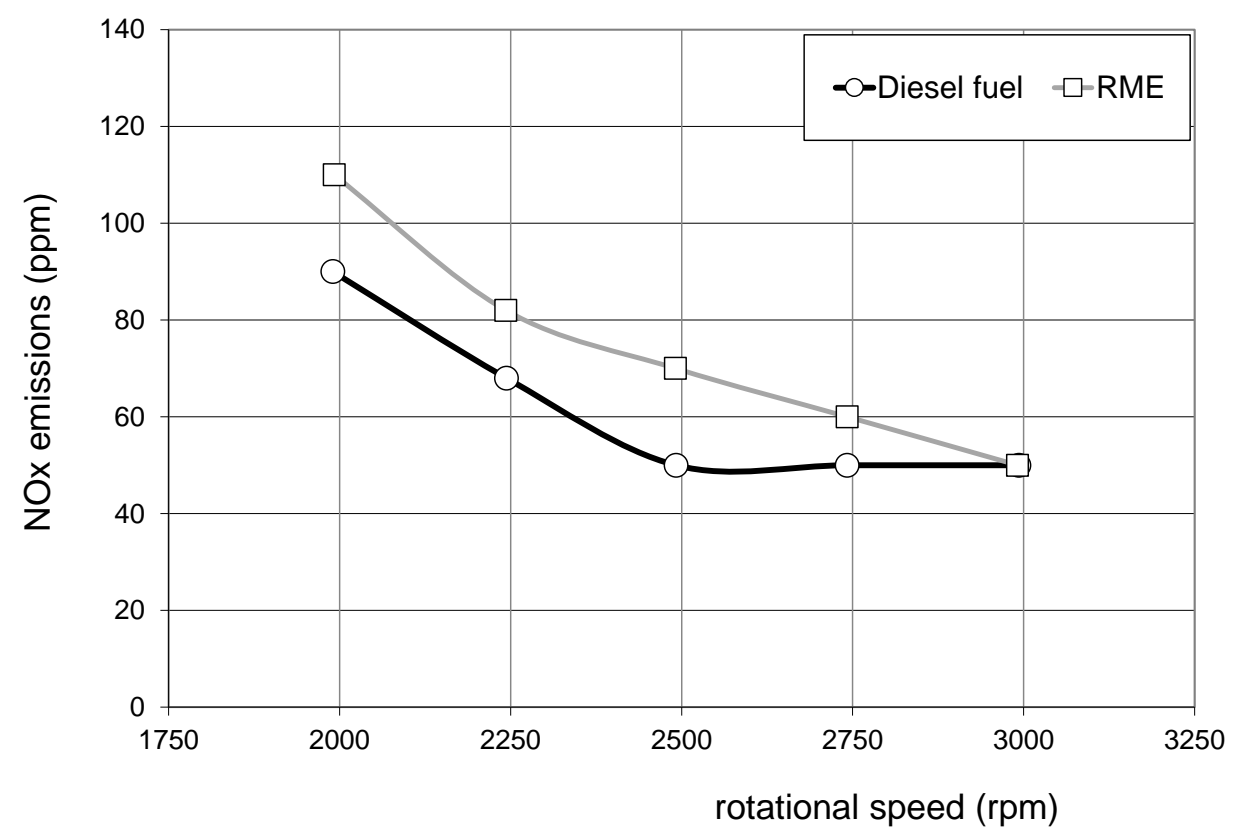

Figure 5. $\mathrm{NO}_{\mathrm{x}}$ concentration in the exhaust as a function of the rotational speed for the two tested fuels.

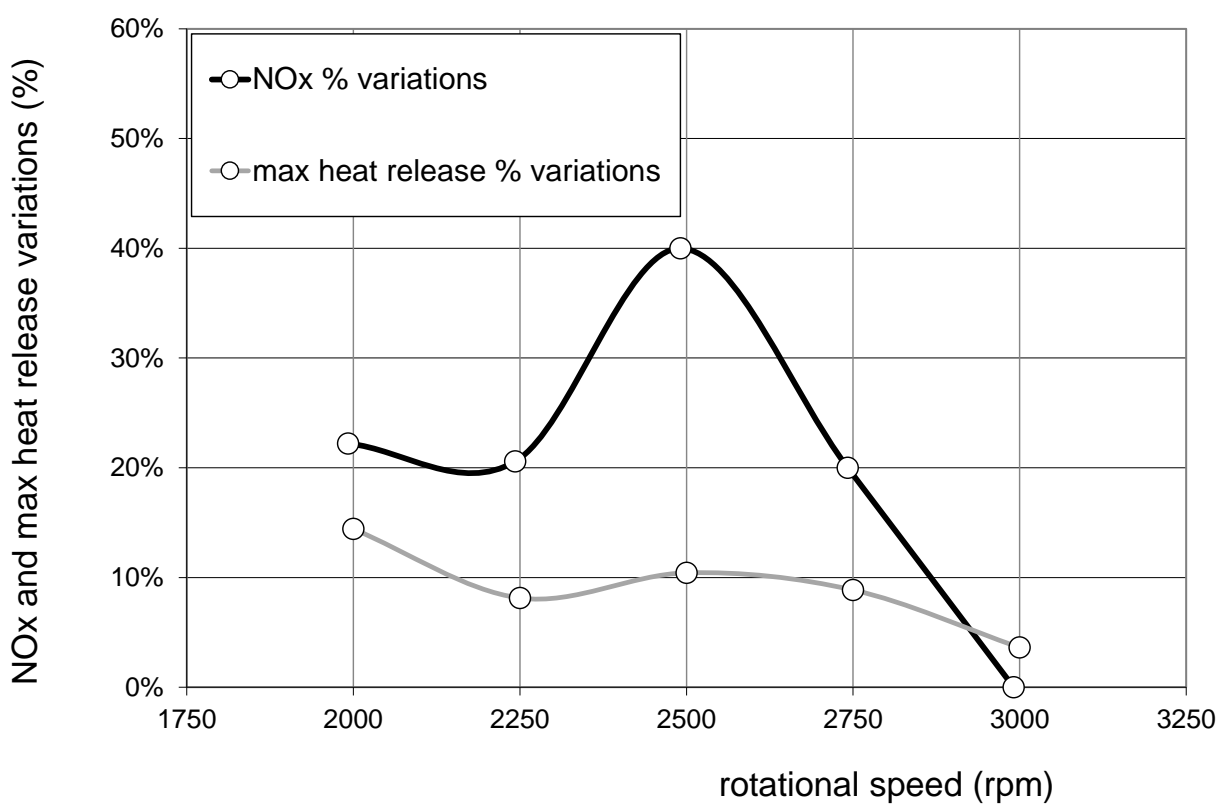

Figure 6. $\mathrm{NO}_{\mathrm{x}}$ emissions and heat release peak variations for the biodiesel at full load as a function of the rotational speed (ref. diesel fueling).

\subsection{Injection Pressure Characteristics and Combustion Analysis}

The fuel pressure in the injection pipe was measured by means of a piezoelectric transducer, and the recorded signals were pressure referenced according to the method proposed in [53]. In fact, the piezoelectric transducers can detect rapid pressure variations but, conversely, give no information on the absolute pressure values; therefore, pressure referencing is needed if absolute pressure values are required or different situations must be compared, as in this case. Indeed, an incorrect pressure referencing may lead to errors in the injection advance and the injection pressure estimation [19]. Thus, in the following figures (Figures 7-11) the pressure values are reported as relative to the fuel's vapor pressure (the differences between vapor pressure of B100 and diesel fuel are neglected as compared to the injection pressure). While not true, this is a reasonable approximation since with injection pressures around 200 bar the error in absolute values is of the order of $1 / 200$. 


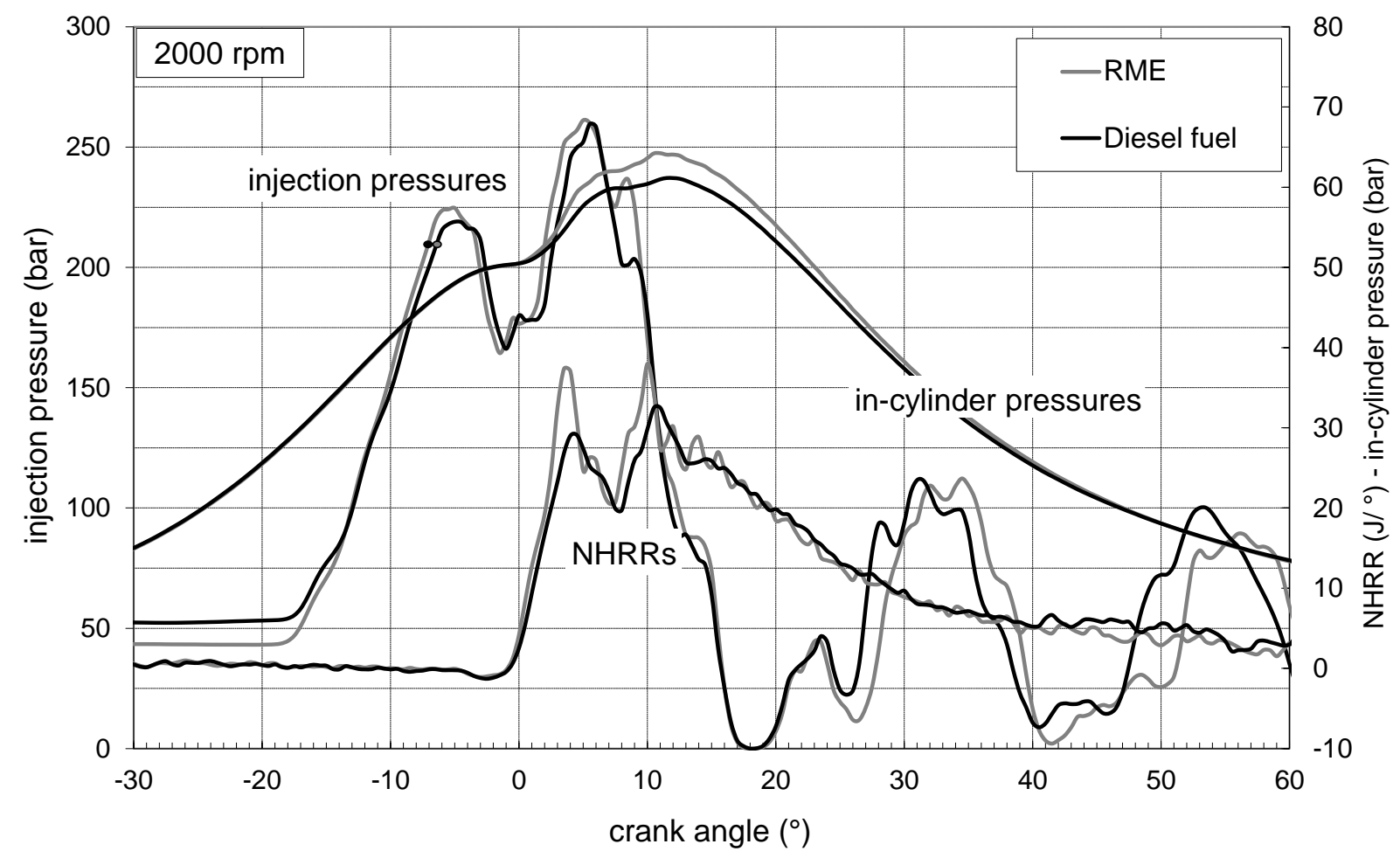

Figure 7. RME and diesel fuel injection pressures, in-cylinder pressures, and NHRR at $2000 \mathrm{rpm}$ and at full load.

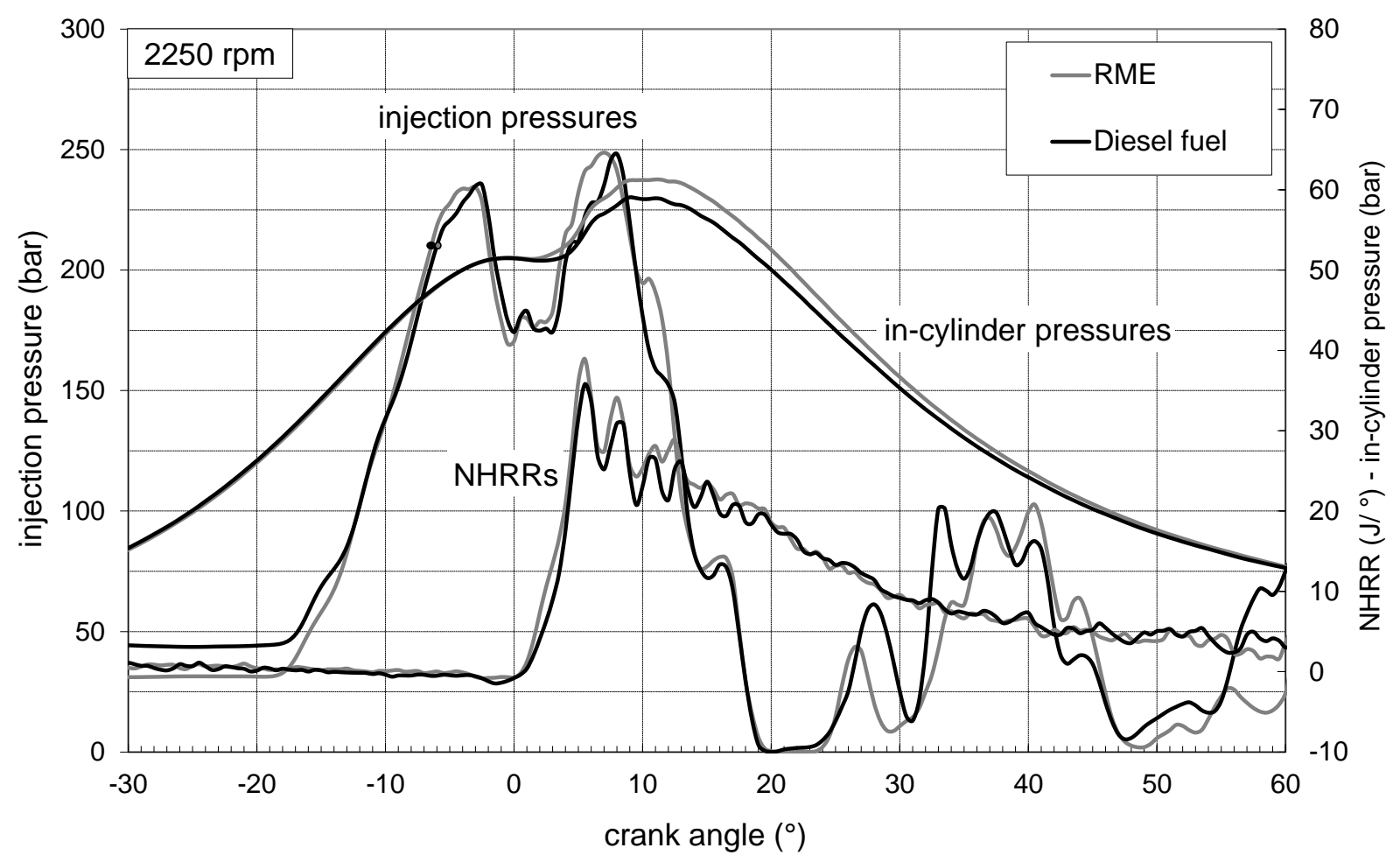

Figure 8. RME and diesel fuel injection pressures, in-cylinder pressures, and NHRR at $2250 \mathrm{rpm}$ and at full load. 


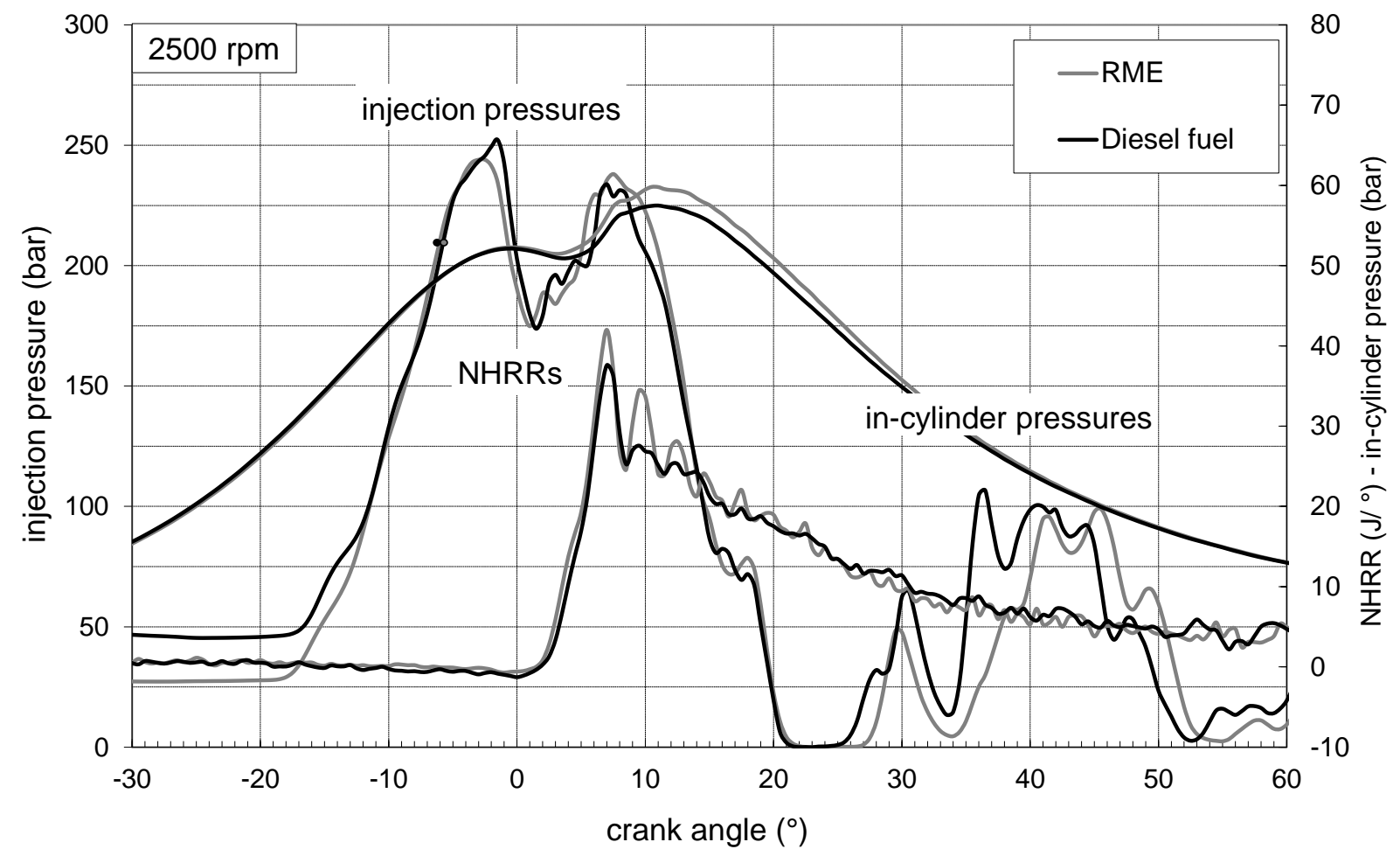

Figure 9. RME and diesel fuel injection pressures, in-cylinder pressures, and NHRR at $2500 \mathrm{rpm}$ and at full load.

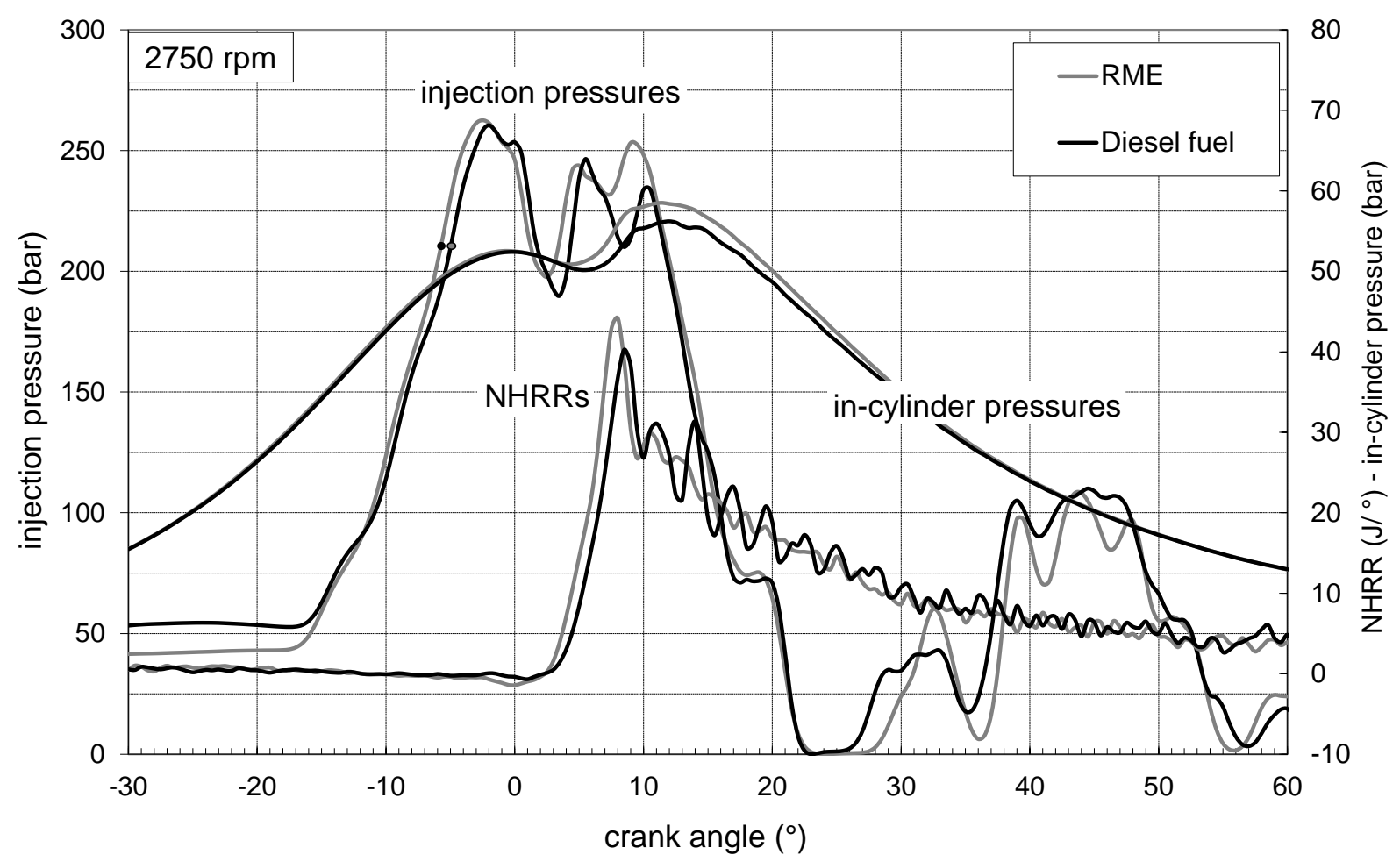

Figure 10. RME and diesel fuel injection pressures, in-cylinder pressures, and NHRR at $2750 \mathrm{rpm}$ and at full load. 


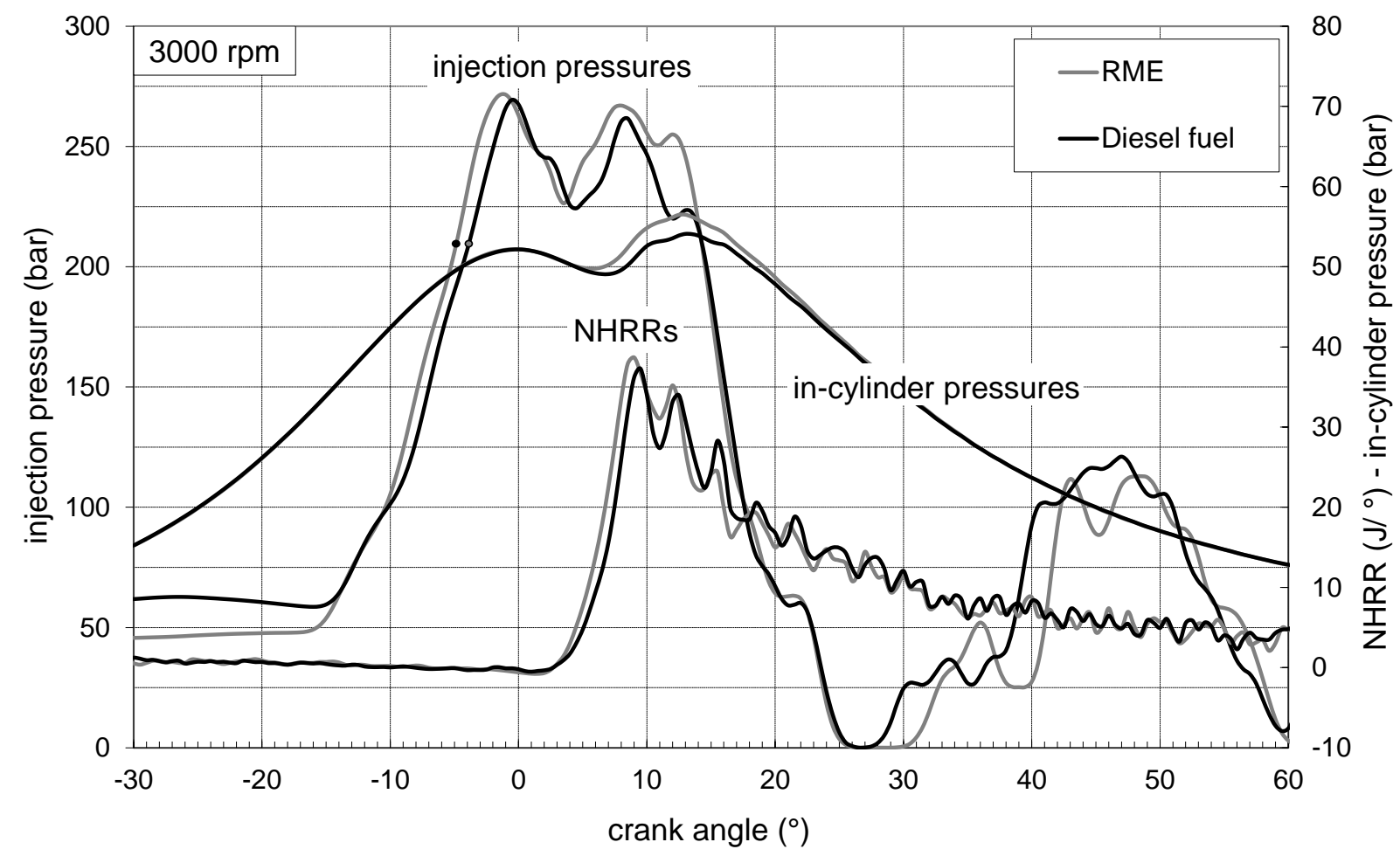

Figure 11. RME and diesel fuel injection pressures, in-cylinder pressures, and NHRR at $3000 \mathrm{rpm}$ and at full load.

With the biodiesel, the fuel pressure recorded in the pipe just before injection was lower at all rotational speeds; nevertheless, the injection pressure was reached in advance (the black circles on the injection pressure curves of Figures 7-11 evidence the crank angular position at which the injector nozzle opening pressure is reached). In fact, due to the lower compressibility of the biodiesel, the pressure rise produced by the pump was faster and also propagated faster toward the injectors (as a consequence of its higher sound speed) [32]. In all the investigated cases, the RME injection pressure curves seem smoother, probably because of the higher viscosity of the RME with respect to the viscosity of diesel fuel.

At the end of injection, cavitation occurred in the pipe. This is identifiable in the zones where the pressure curves, which had previously fallen steeply (see the pressure signals at $17^{\circ}, 19^{\circ}, 21^{\circ}, 23^{\circ}$, and $26^{\circ} \mathrm{CA}$, for engine rotational speeds of $2000 \mathrm{rpm}, 2250 \mathrm{rpm}$, $2500 \mathrm{rpm}, 2750 \mathrm{rpm}$, and $3000 \mathrm{rpm}$, respectively), rapidly flatten and the pressure remains almost constant at the vapor pressure despite the transient nature of the phenomenon. At the same time, it is possible to observe an intense pressure wave travelling to-and-fro in the pipe. As the speed increases, the angular interval where cavitation is detected is longer with the RME than with diesel.

By analyzing the injection pressure signals in a higher detail, some interesting considerations can be drawn regarding the injection advance and the injection duration. As a premise, since the needle lift was not measured, the SOI was assumed to coincide with the crank angle position at which the fuel pressure reaches the value of the injector nozzle opening pressure (i.e., 210 bar). Similarly, the end of injection (EOI) was assumed to coincide with the crank angle position at which the fuel pressure reaches the value of the injector nozzle closing pressure (i.e., 150 bar). As an example, the SOIs, EOIs, and the consequent injection durations are reported in Figure 12 in the case of $2500 \mathrm{rpm}$.

The effect of the rotational speed on the differences in the injection advance and injection duration will be commented on by analyzing Figures 13 and 14, respectively. 


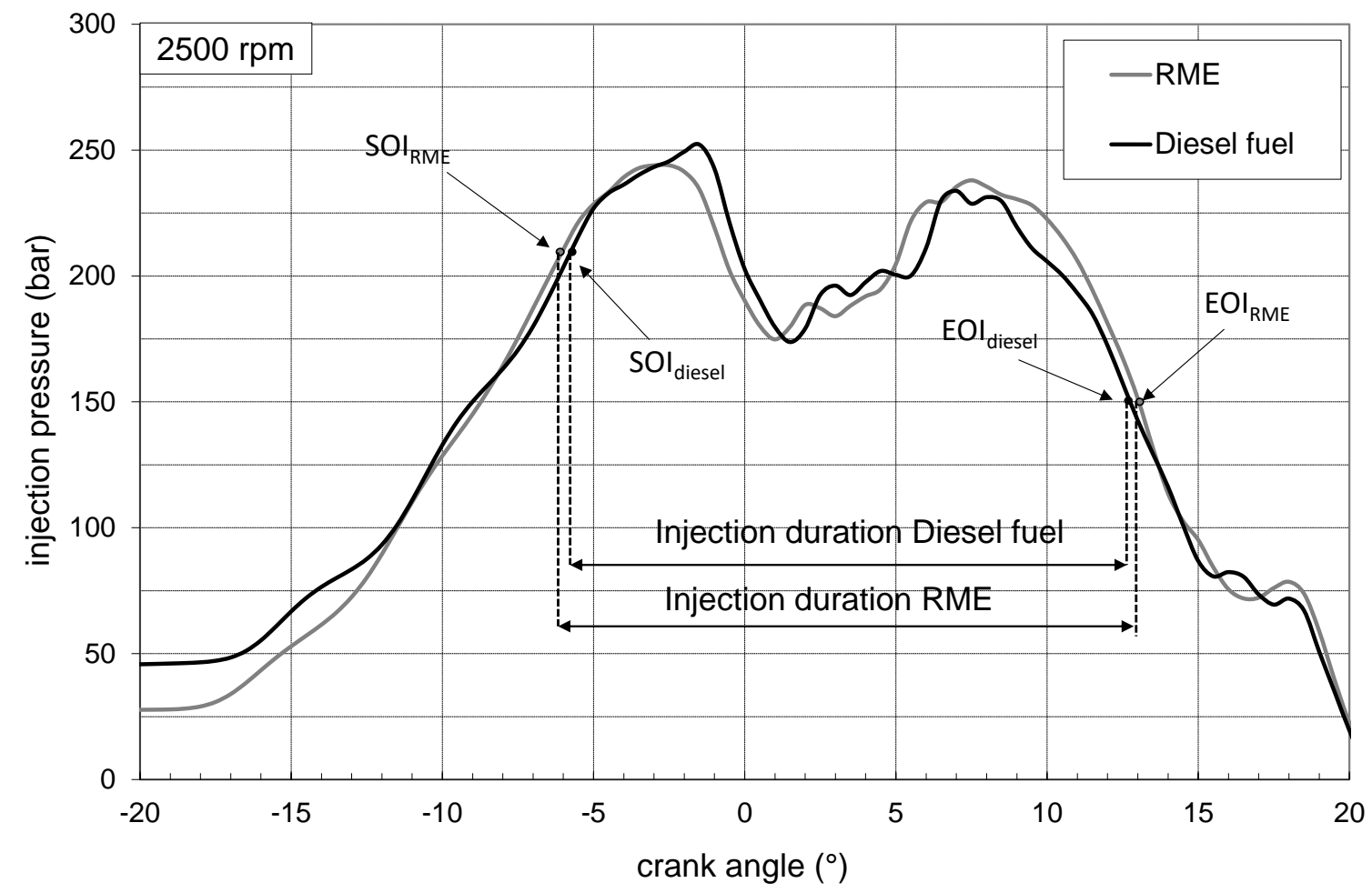

Figure 12. Injection durations with the RME and the diesel fuel at $2500 \mathrm{rpm}$ and at full load.

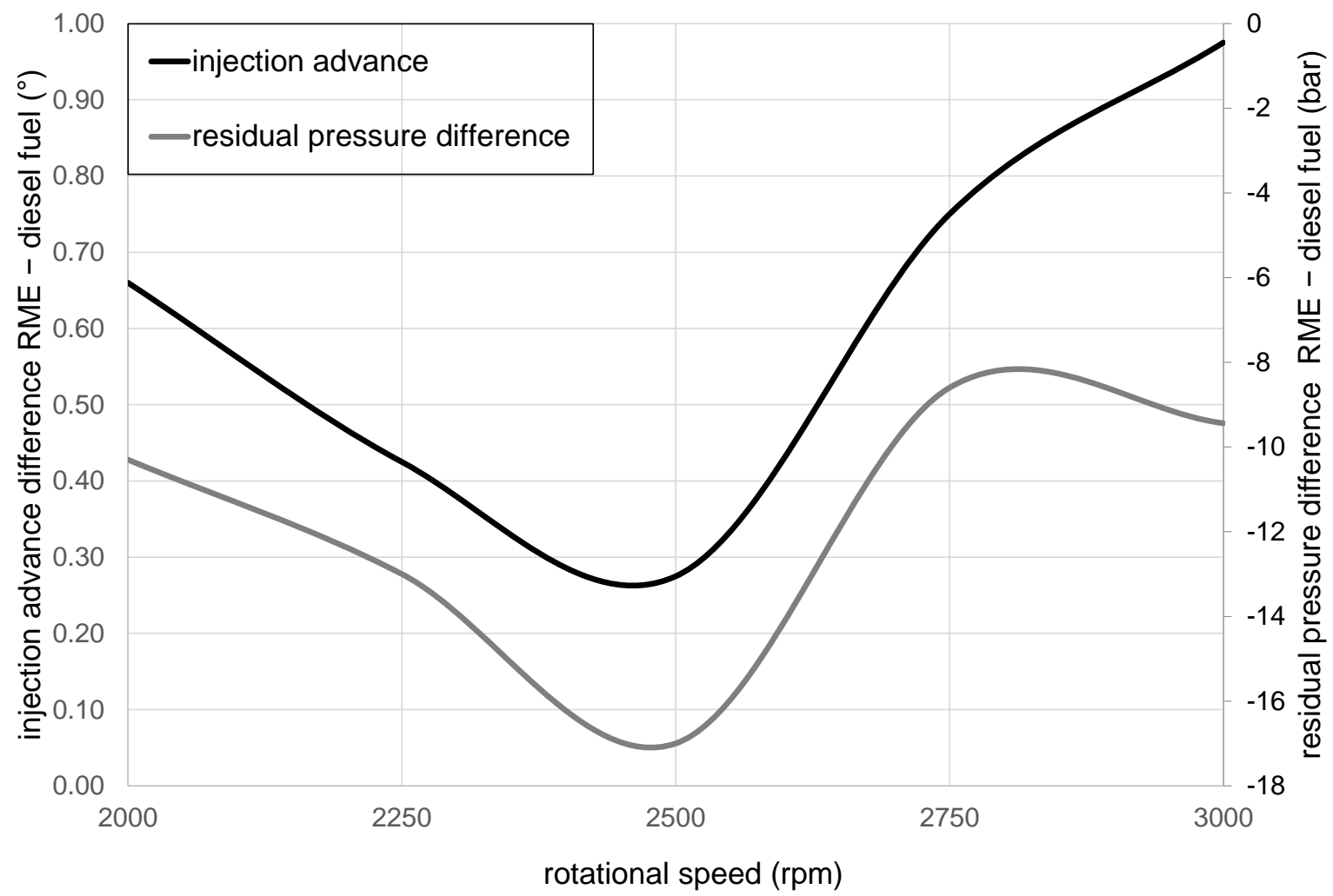

Figure 13. Injection advances with the RME and the diesel fuel and residual pressure difference between the same two fuels as a function of the engine speed and at full load. 


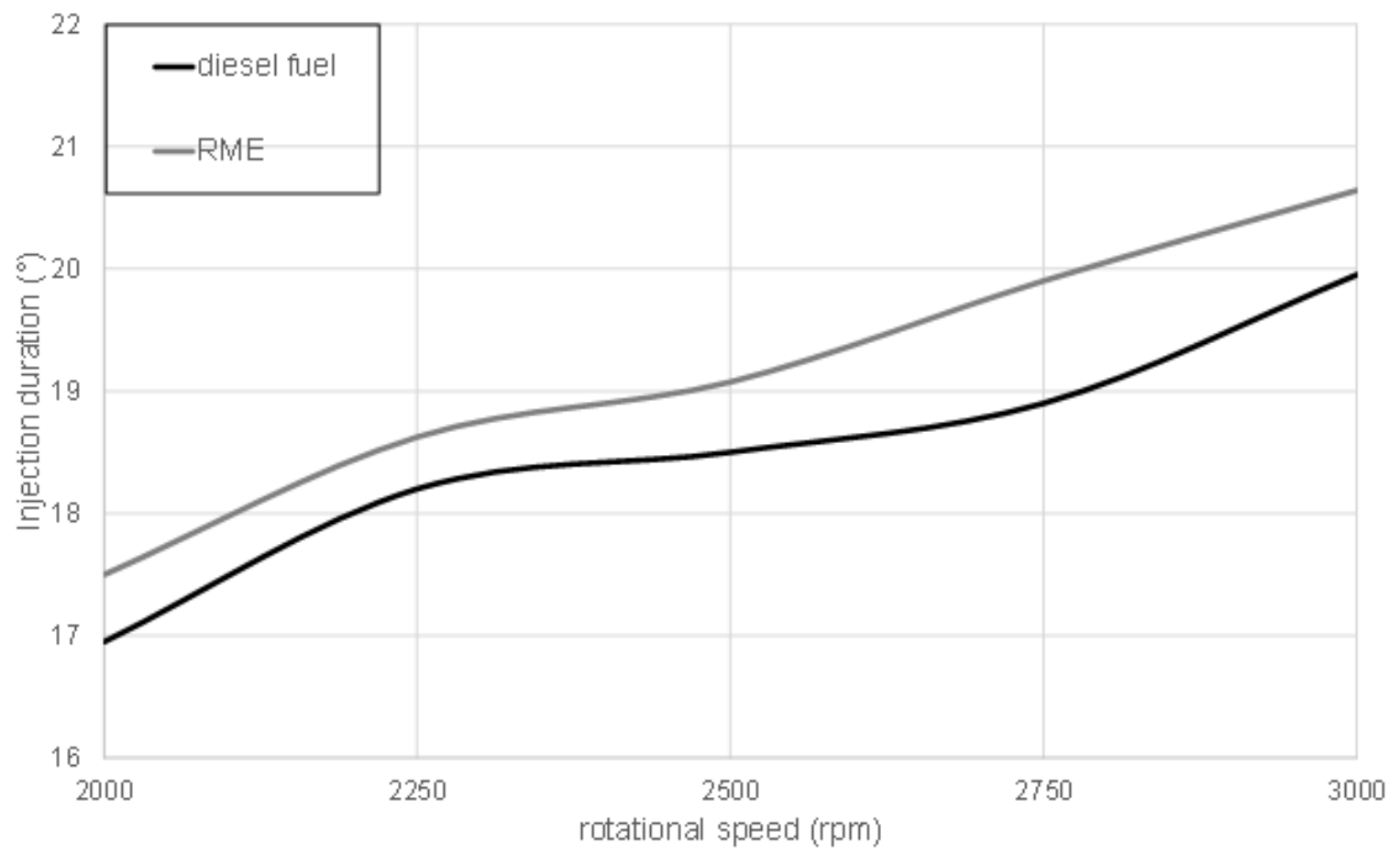

Figure 14. RME and diesel fuel injection pressures, in-cylinder pressures, and NHRR at $3000 \mathrm{rpm}$ and at full load.

As expected, due to the higher bulk modulus, the injection with the RME is advanced by a minimum of $0.27^{\circ} \mathrm{CA}$ at $2500 \mathrm{rpm}$ and a maximum of around $1^{\circ} \mathrm{CA}$ at $3000 \mathrm{rpm}$. These findings confirm the so-called biodiesel inadvertent injection advance effect, but also evidence a nonmonotone trend with the rotational speed. The reason for this nonmonotone behavior can be explained by having a look at the variation in the rotational speed of the residual pressure differences between the two fuels.

In fact, as shown in the graphs in Figure 13, the decrease in the residual pressure, caused by the use of the RME, which partially compensates for the advancing effect of its higher bulk modulus, has a very similar trend to that of the advance-only the data at $3000 \mathrm{rpm}$ seem against the above-evidenced behavior.

Now, let us reconsider the results in Figure 6. Surprisingly, it appears that the biodiesel $\mathrm{NO}_{x}$ effect is more evident at $2500 \mathrm{rpm}$, where the injection advance differences between the two fuels are the lowest. However, as already evidenced by Figure 6, this is explainable by the higher peak of the heat release, which occurs despite the reduced advance. This is another example of the not always straightforward behavior of biodiesel as concerns the combustion analysis and $\mathrm{NO}_{x}$ formation mechanisms.

As is visible in Figure 14, the total injection angle increases with the rotational speed for both fuels, but the injection lasts almost 3-4\% longer when using RME.

These results contribute to explain the increase of the injection rate of the RME with respect to diesel fuel. Overall, the higher injection pressures and the longer injection duration cause an increase of the injected mass per cycle of RME, which in the end compensates for the reduction of the fuel $\mathrm{LHV}_{\mathrm{m}}$, thus yielding almost the same torque values for both fuels.

\subsection{Combustion Characteristics}

As previously shown in Figures 7-11, the NHRR graphs and the general combustion characteristics are those of a classic direct injection diesel engine for both biodiesel and diesel fuel. Starting from the SOI, the HRR is slightly negative during the ignition delay period due to the cooling effect of fuel vaporization; then, in the initial phase of combustion, a rapid HRR occurs because of the combustion of the fuel that has mixed with air during the ignition delay. After this phase, the combustion continues slowly until most of fuel is 
burned; the final combustion phase is the late combustion, which continues until the end of the expansion stroke. Instead, some differences between the biodiesel and the diesel fuel occurred regarding the SOC and HRR values. As confirmed by the positions of the local minima of the in-cylinder pressure 1st derivative in the Figures 15-19, the SOC for the biodiesel was almost the same as for the diesel fuel at $2000 \mathrm{rpm}$; then, as the rotational speed increased, the SOC of the biodiesel was slightly shifted to an earlier stage, with the advance reaching about $0.75^{\circ} \mathrm{CA}$ at $3000 \mathrm{rpm}$.

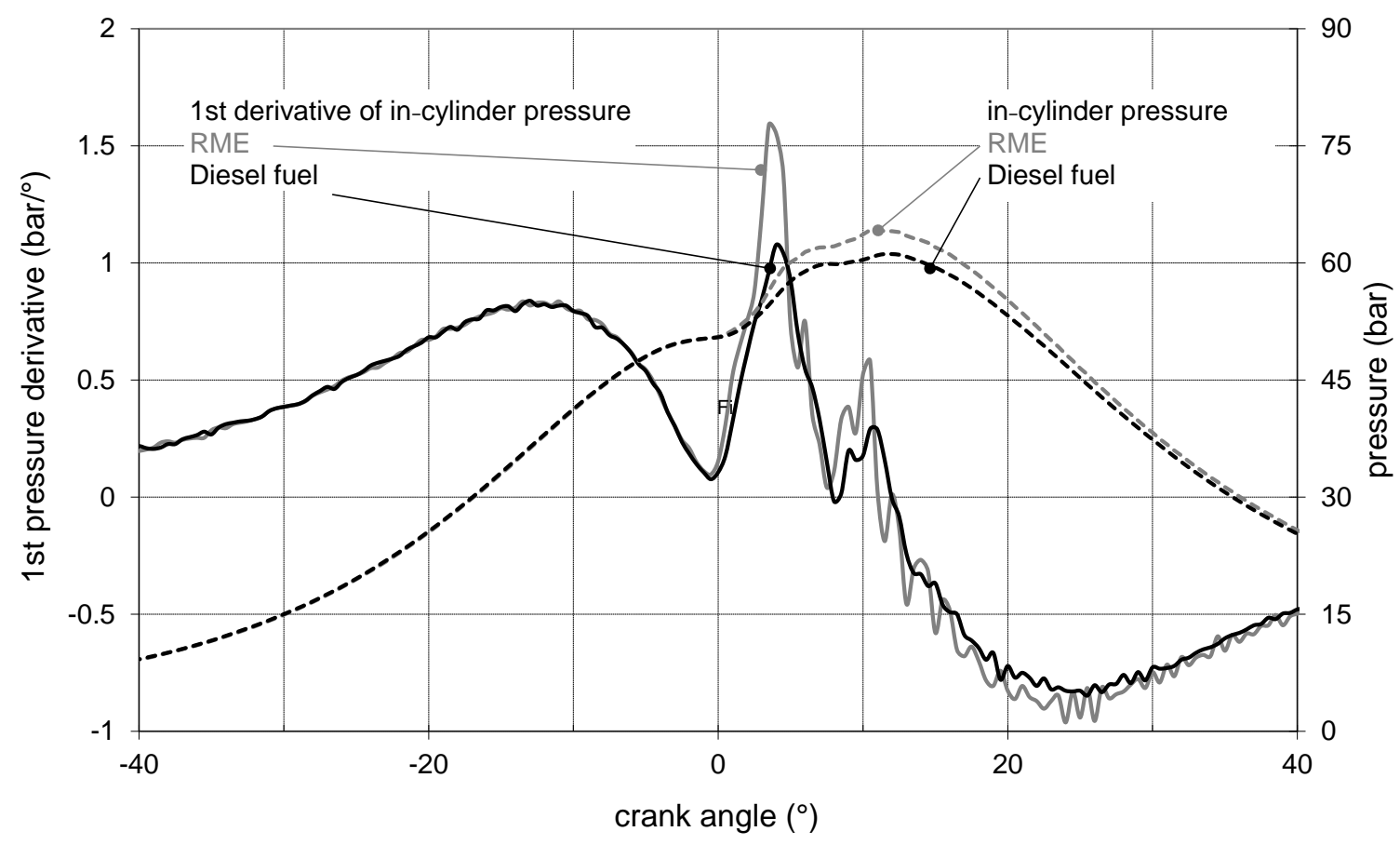

Figure 15. RME and diesel fuel in-cylinder pressures and rate of pressure rise at $2000 \mathrm{rpm}$ and at full load.

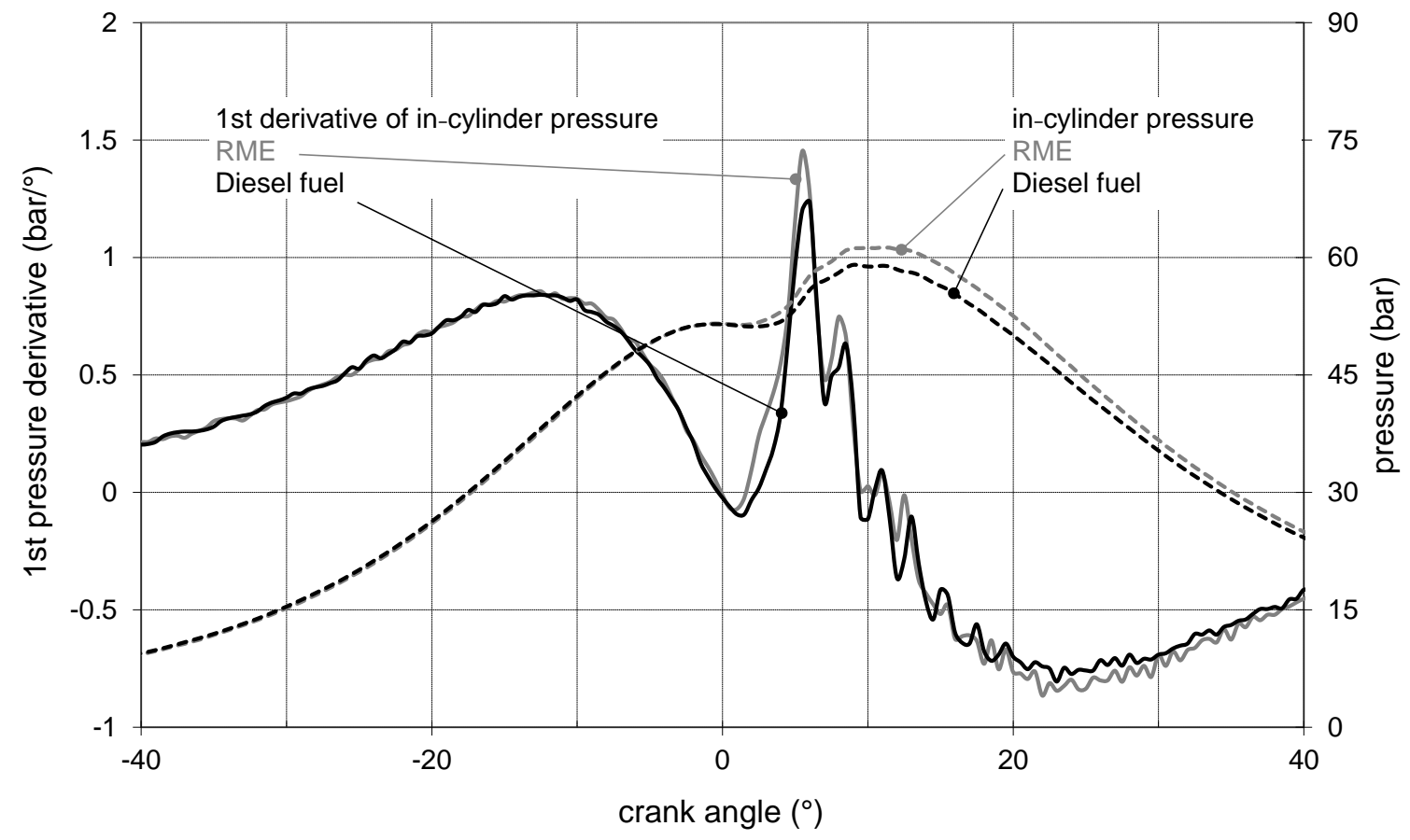

Figure 16. RME and diesel fuel in-cylinder pressures and rate of pressure rise at $2250 \mathrm{rpm}$ and at full load. 


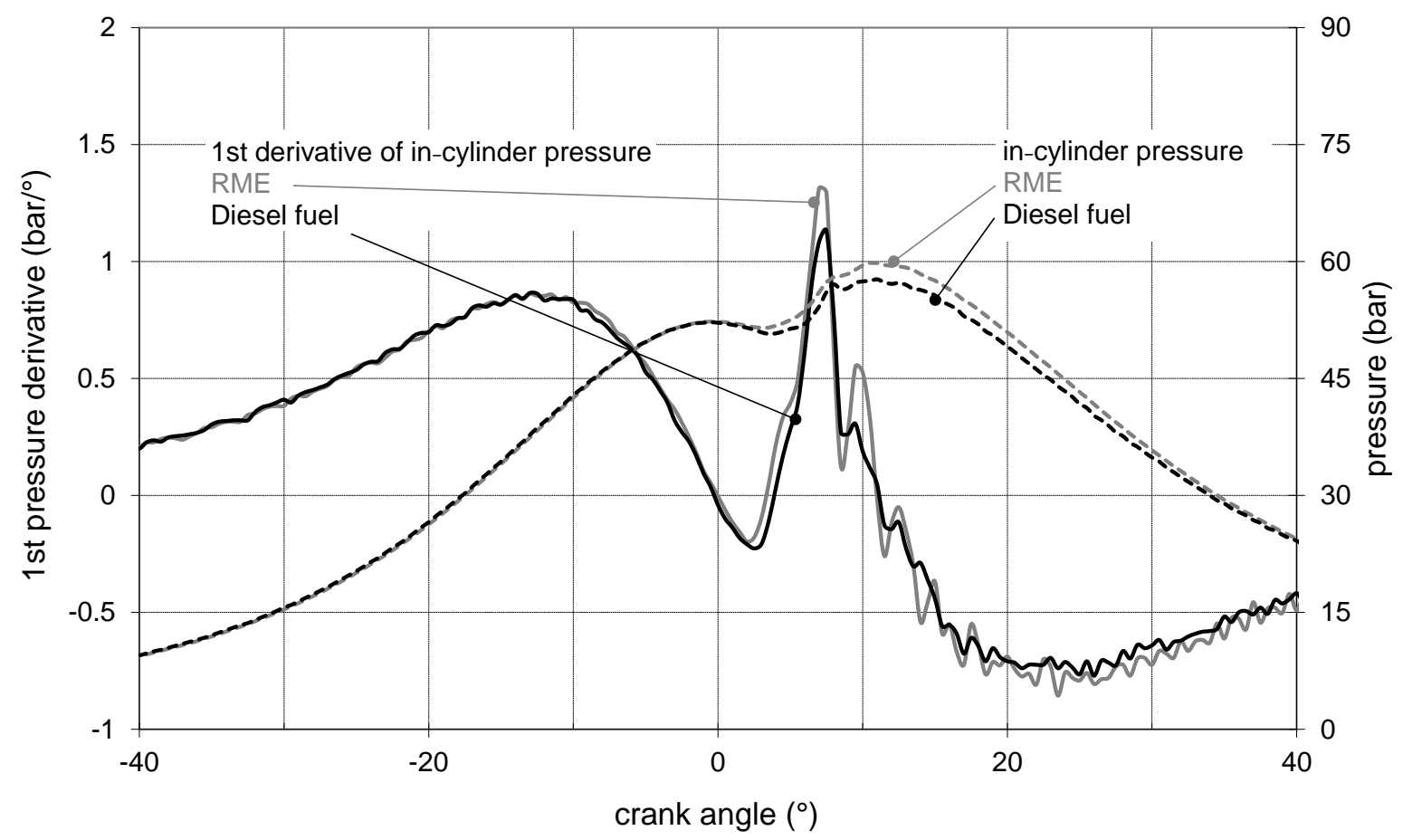

Figure 17. RME and diesel fuel in-cylinder pressures and rate of pressure rise at $2500 \mathrm{rpm}$ and at full load.

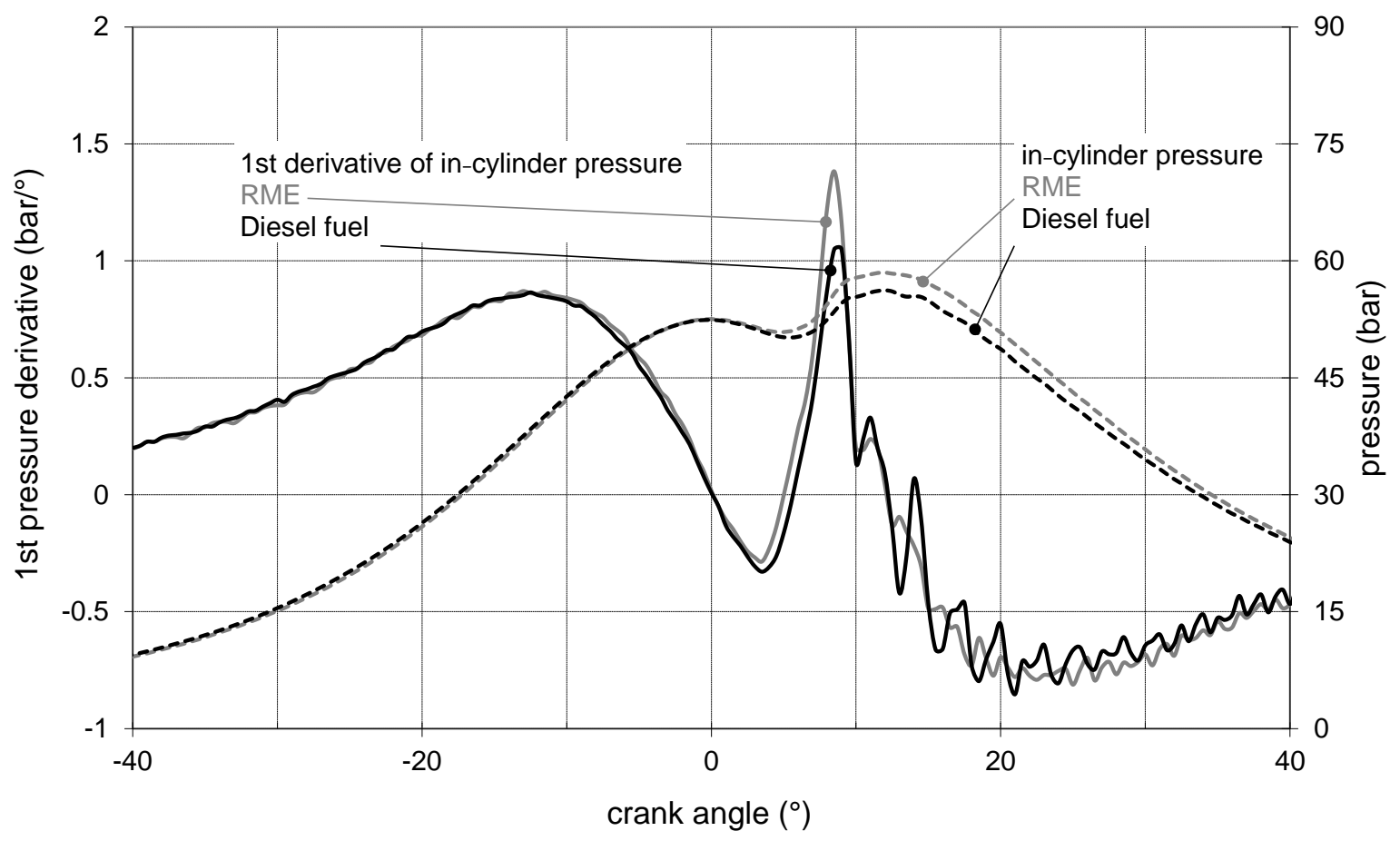

Figure 18. RME and diesel fuel in-cylinder pressures and rate of pressure rise at $2750 \mathrm{rpm}$ and at full load.

As the advances in the SOC were almost identical to the SOI advances, the angular ignition delays were comparable for the two fuels. This behavior can be interpreted by considering that the reduction of the chemical ignition delay due to the higher cetane number of the RME is probably compensated by an increased physical ignition delay due to a worse atomization and mixture formation. As shown in paragraph 3.2, the injection pressure of the RME and diesel fuel were similar, and the worse mixture formation is attributable to the RME's higher surface tension, higher flash point, and poorer volatility. 


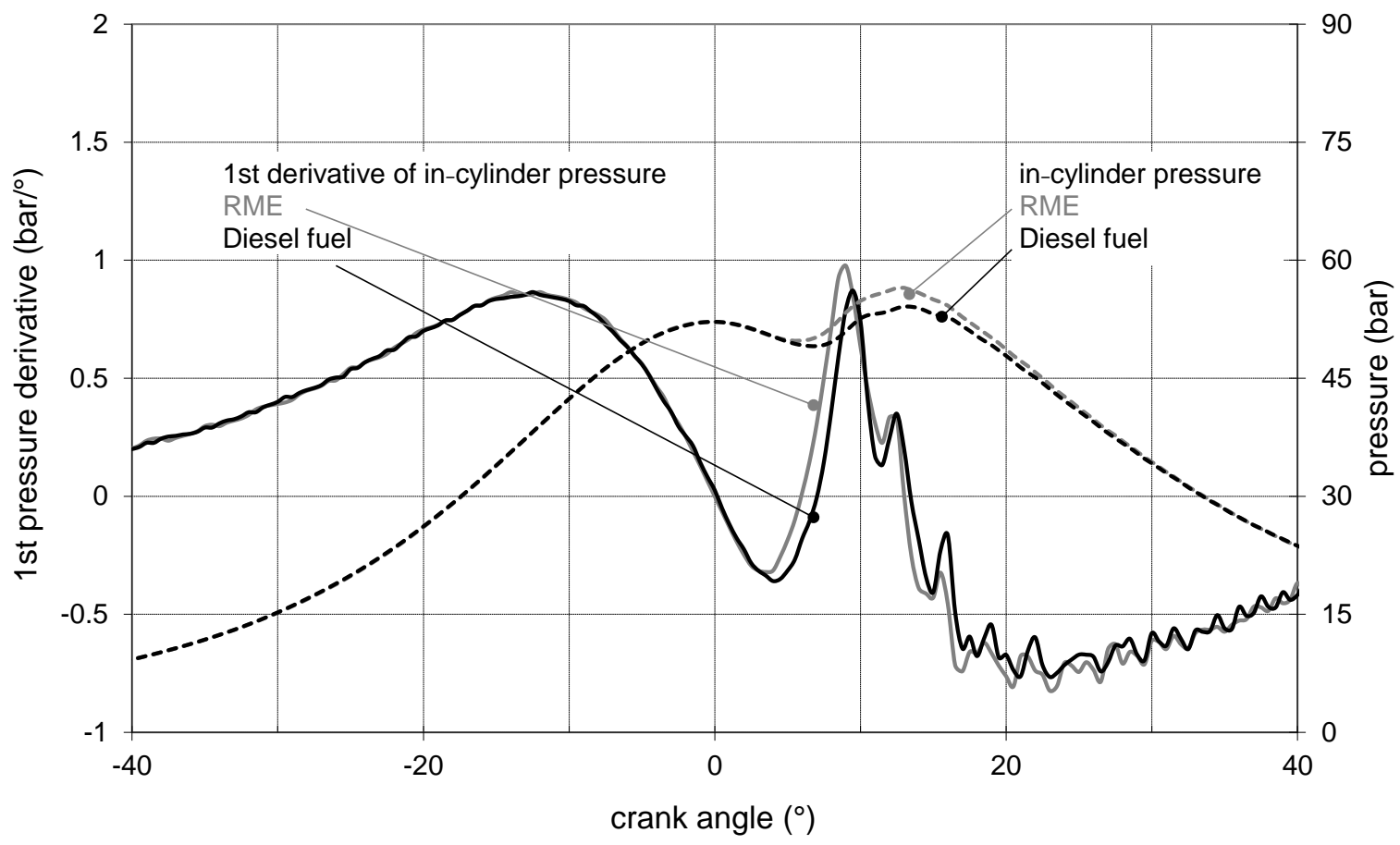

Figure 19. RME and diesel fuel in-cylinder pressures and rate of pressure rise at $3000 \mathrm{rpm}$ and at full load.

After the SOC, the NHRR curves of biodiesel became steeper than those of diesel fuel, and a higher peak was reached due to an increased amount of fuel undergoing premixed combustion. This also caused higher rates of pressure rise and higher pressure peaks (Figures 15-19).

The higher values of NHRR are likely to be a consequence of the biodiesel molecular composition; indeed, as the oxygenated fuel evaporates, the oxygen bound in the fuel is progressively released, thus enhancing the flame speed and resulting in a higher HRR.

In order to assess the effect of the variation of the injection timing on the performance and emissions, and to try to offset the biodiesel $\mathrm{NO}_{\mathrm{x}}$ effect, the standard injection timing has been modified starting from the reference value of $16^{\circ} \mathrm{CA}$ before top dead center (BTDC). Starting from this reference injection condition, and based on the manufacturer's technical indications, two other configurations were set, properly adjusting the number of shims in the injection pump: a late injection equal to $14^{\circ} \mathrm{CA}$ BTDC, and an early injection equal to $18^{\circ} \mathrm{CA}$ BTDC.

Observing Figure 20, it is possible to note that a change of fueling has a limited effect on the engine torque. Moreover, consider that, for example, the differences in torque at $2500 \mathrm{rpm}$ are of the same magnitude of the measurement error, and therefore no precise indications can be depicted. Nevertheless, in the analysis of the trends one can observe that a slightly higher value is obtained with the RME by retarding the injection timing to $+2^{\circ} \mathrm{CA}$. The trends with the RME with the standard SOI, and by anticipating the injection, are practically overlapping with the diesel fueling.

As concerns the specific fuel consumption (Figure 21), a higher influence of the SOI and of the fueling can be appreciated. Specifically, by anticipating the SOI $\left(-2^{\circ} \mathrm{CA}\right)$, the BSFC with the RME becomes comparable with that of the diesel fuel at all the rotational speeds despite the lower $\mathrm{LHV}_{\mathrm{m}}$ of biodiesel, which entails a higher global conversion efficiency. With both a standard SOI and a retarding of the injection $\left(+2^{\circ} \mathrm{CA}\right)$, the BSFC increases consistently with the lower $\mathrm{LHV}_{\mathrm{m}}$ of biodiesel, and a delay in the injection shows a slightly higher performance at high rotational speeds than at lower rpms.

As concerns the emissions, the use of RME consistently reduced the concentration of $\mathrm{CO}$ in the exhaust at all the operative conditions, as shown in Figure 22. The highest abatement is obtained by anticipating the SOI by two degrees. This outcome is a consequence of 
the higher combustion temperature and pressure, which facilitate the shift of the oxidation reactions toward a complete conversion to $\mathrm{CO}_{2}$. However, the higher oxygen content and the higher HRR with the RME grants lower $\mathrm{CO}$ emissions for all the injection timings.

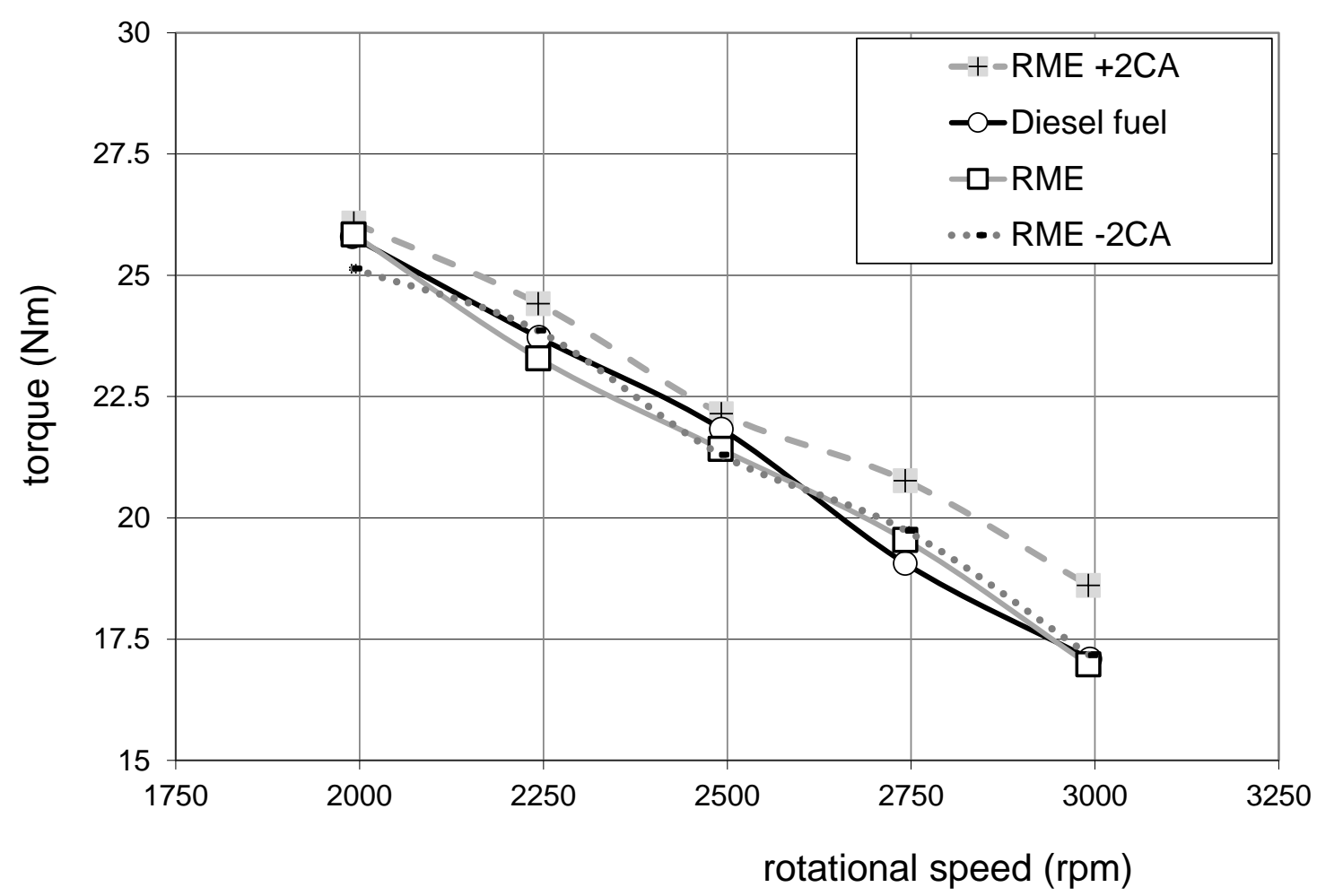

Figure 20. Torque as a function of the rotational speed at full load, for different values of the SOI and for the two tested fuels.

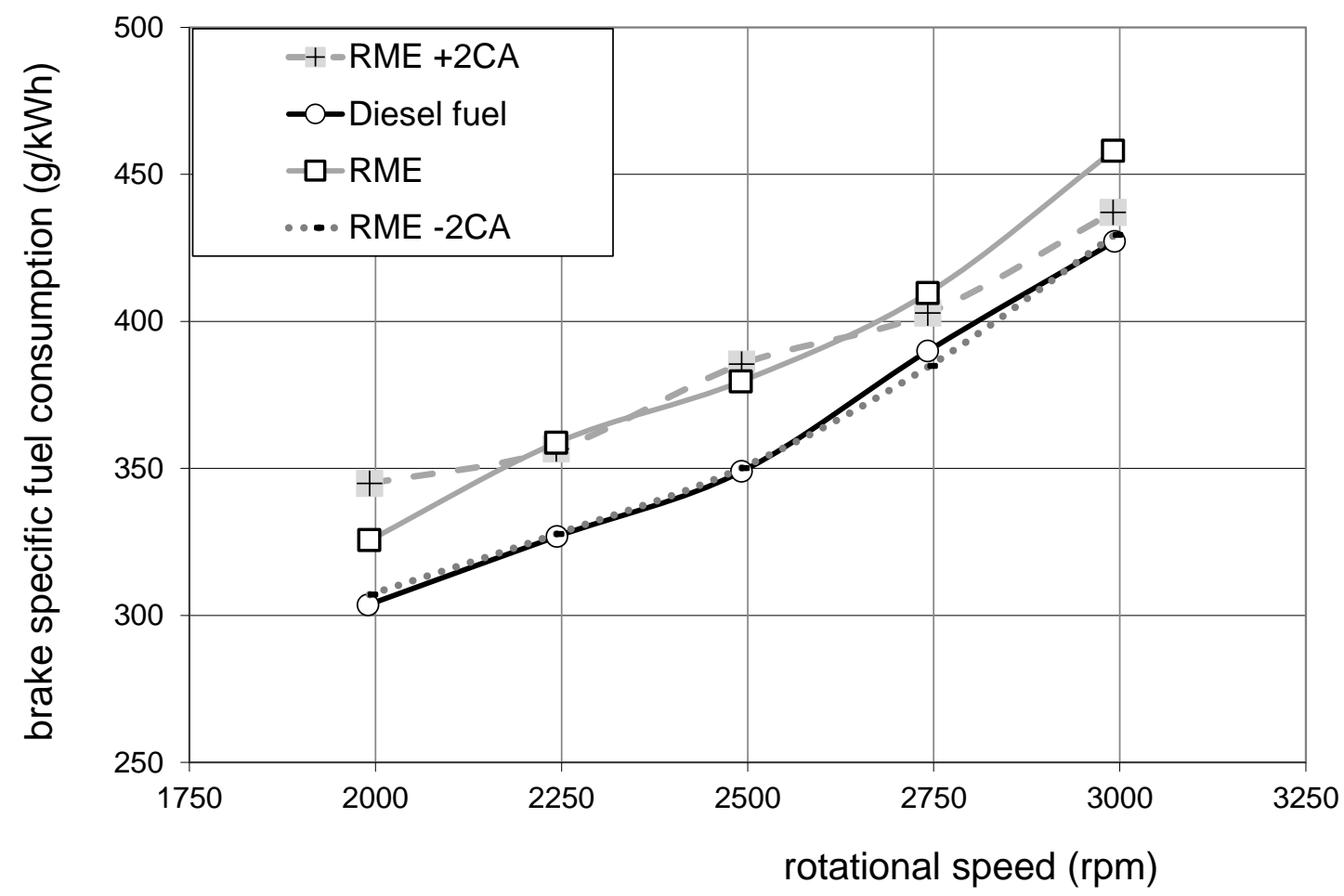

Figure 21. Brake specific fuel consumption as a function of the rotational speed at full load, for different values of the SOI and for the two tested fuels. 


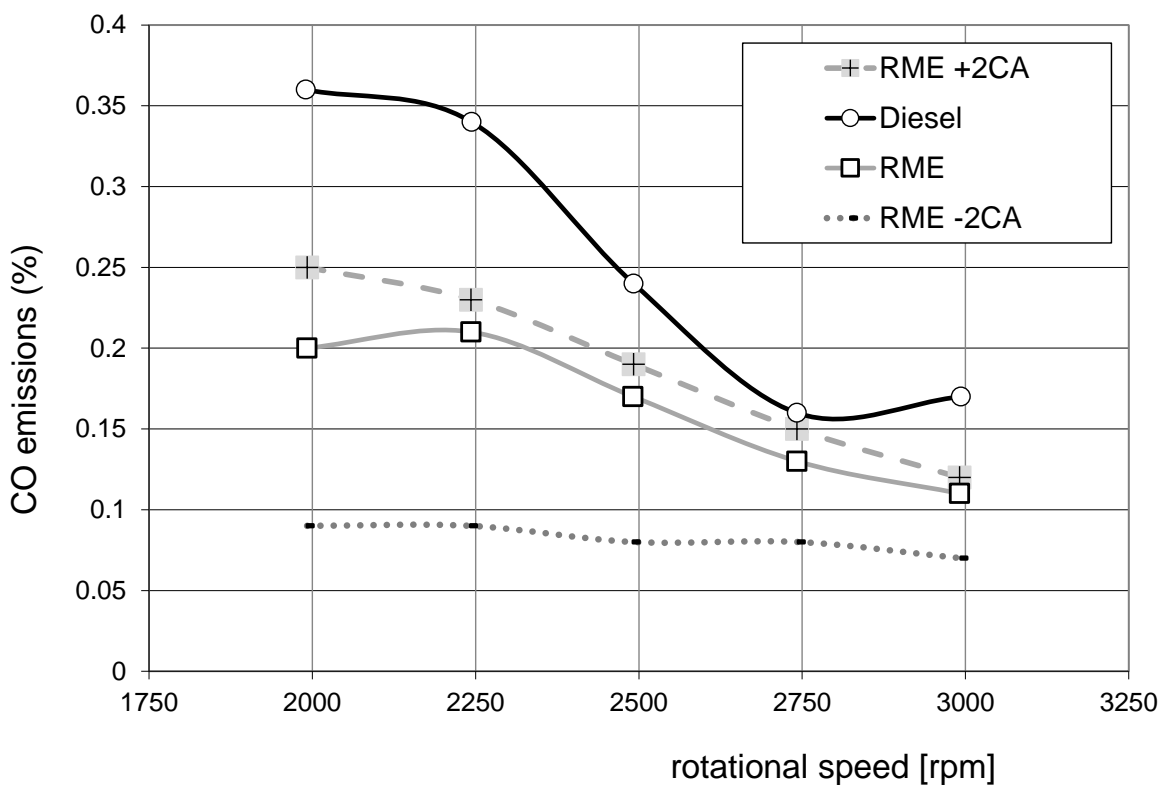

Figure 22. CO emissions variations for the biodiesel at different values of the SOI and at full load (ref. diesel emissions with $16^{\circ} \mathrm{CA}$ of injection advance).

As is visible in Figure 22, whatever the injection advance, the use of biodiesel allows for a reduction of the $\mathrm{CO}$ emissions. A further decrease can be obtained when shifting to the RME by reducing the injection advance. The higher percentage decreases can be observed in correspondence with the low rotational speeds. Moving toward the higher rpms, the positive effects decrease somewhat until an inversion occurs at about $2750 \mathrm{rpm}$.

Figure 23 shows the comparison of the concentrations of $\mathrm{NO}_{\mathrm{x}}$ between the diesel and the RME, where the $\mathrm{NO}_{x}$ effect can be clearly identified; however, the negative $\mathrm{NO}_{x}$ effect seems to disappear, shifting the SOI to $+2^{\circ} \mathrm{CA}$ (i.e., in correspondence with an angle causing the trend to overlap with that of the diesel fuel).

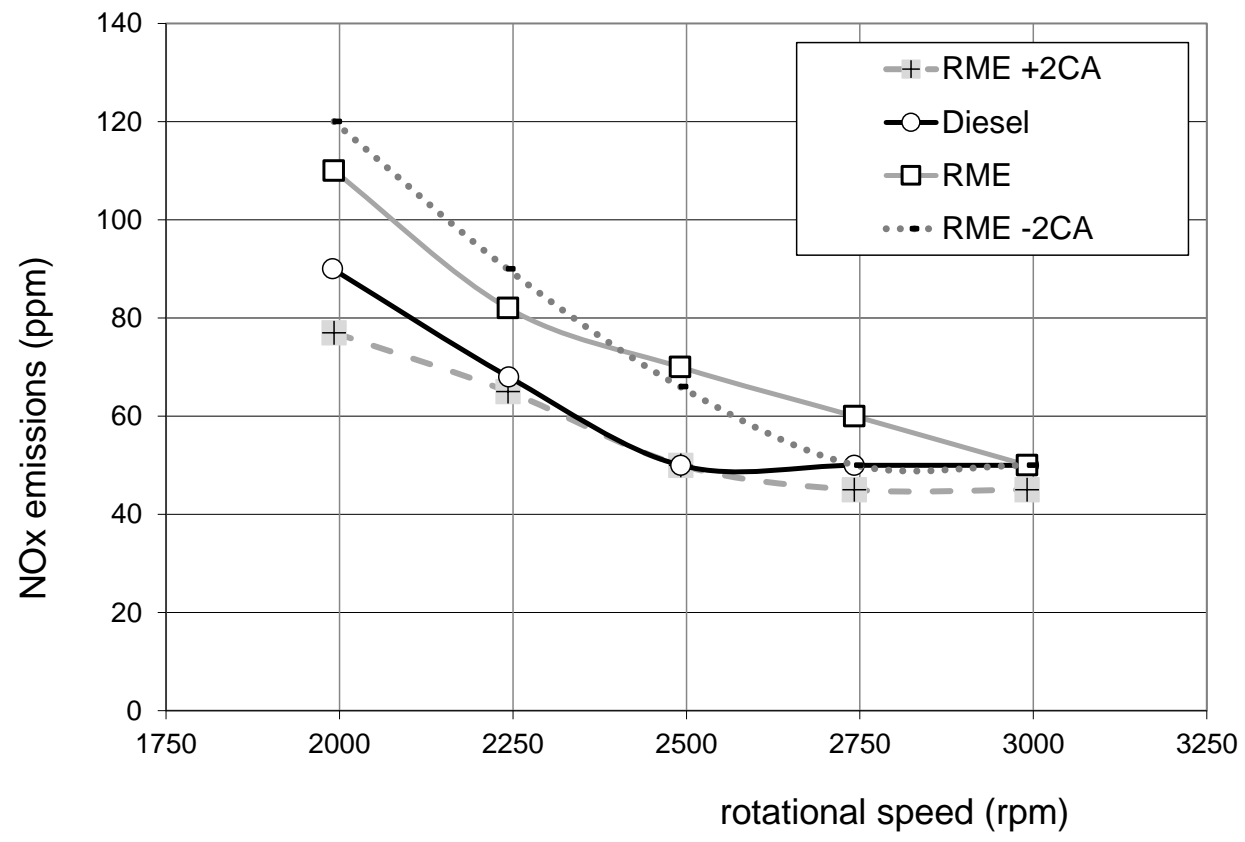

Figure 23. $\mathrm{NO}_{\mathrm{x}}$ emissions variations for the biodiesel at different values of the SOI and at full load (ref. diesel emissions with $16^{\circ} \mathrm{CA}$ of injection advance). 
What seems a little surprising is the reduction of $\mathrm{NO}_{\mathrm{x}}$ in the 2500-2750 rpm range when the injection of RME is anticipated.

This is another example of the not-so-straightforward behavior of biodiesel as concerns $\mathrm{NO}_{\mathrm{x}}$ emissions. The factors influencing this behavior are, in effect, not independent but comprehensive and interactive, and include, besides the biodiesel properties, engine loads and also, as in this case, engine speeds to influence the final determinant for the $\mathrm{NO}_{\mathrm{x}}$ emission of biodiesel combustion temperature [31].

Unfortunately, in this case, we are not able to correlate this behavior to the heat release, as no in-cylinder pressure recordings were available for these tests.

Nevertheless, we can conclude that retarding the SOI by two degrees of CA with respect to the factory settings seems to be the best compromise for the performance and emissions of the engine fueled with the RME. Indeed, (i) the $\mathrm{NO}_{x}$ effect is eliminated, (ii) the $\mathrm{CO}$ emissions do not increase compared to diesel combustion, (iii) the torque improves, and the global efficiency is acceptable.

\subsection{Comments on the Results and Comparison with Literature Studies}

In this section, the presented performance results are commented on and compared to other similar studies available in the literature. The analysis focuses on both the combustion and the emissions. When the RME is used to fuel the studied engine, and having an in-line fuel pumping system:

- the brake torque at full load is minimally affected, and the variation of the torque with the diesel oil and the RME fueling is within the accuracy of the measuring instrumentation;

- the $\mathrm{NO}_{\mathrm{x}}$ emissions increase between 9\% (at higher rotational speeds) and 40\% (at lower rotational speeds);

- $\quad$ the SOI is slightly advanced (of a maximum of about $0.75^{\circ} \mathrm{CA}$ ) and the SOC takes place earlier, accordingly;

- when the fuel delivery ends, the pressure in the injection system drops rapidly, causing severe cavitation in the fuel, and the cavitation period lasts more with the RME as, due to its higher bulk modulus, the pressure drop is the steeper;

- the pressure in the fuel line just before injection (i.e., the residual pressure) is lower with the RME, probably due to the combined effects of a more intense cavitation at the end of the injection and the higher fluid viscosity;

- the maximum fuel pressure during the injection is only slightly higher with the RME if a correct pressure reference is taken into account, and thus the effect of the residual pressure decrease with RME is considered;

- the net heat release during the premixed phase is steeper, and a higher peak of heat release is reached;

- with the same pump settings, the mass of injected fuel is higher with the RME than with the mineral diesel fuel due to the increased injection duration and the slightly higher injection pressure;

- the control of the fuel injection timing of the line pump can help to counterbalance the $\mathrm{NO}_{x}$ effect, and with the RME, a retarding of $2^{\circ} \mathrm{CA}$ on the standard timing can offset the increase of the $\mathrm{NO}_{x}$ emissions so that the other performance parameters remain comparable to a standard fueling.

The results show that, apart from a slight advance in the SOC caused by the advance in the SOI, the RME differs from diesel fuel for the higher HRR during the first part of the combustion. This causes a higher peak of heat release, a higher rise in pressure, and in-cylinder peak pressure, and thus a higher combustion temperature. Considering that the atomization of biodiesel is poorer than that of diesel fuel, this behavior is likely to be due to the oxygen bound in the fuel molecules. This is consistent with the literature results, in particular with Labeckas G. and Slavinskas S. [39] who, having tested RME on a four-cylinder, water-cooled, direct injection, naturally aspirated diesel engine, stated that "in contrast to air-borne oxygen, the fuel-based oxygen accelerates the combustion 
process from within the fuel-rich spray patterns themselves", and added: "this advantage is especially beneficial at heavy loads".

As far as the biodiesel $\mathrm{NO}_{\mathrm{x}}$ effect is concerned, the bound oxygen has a twofold effect: boosting the thermal production of $\mathrm{NO}_{\mathrm{x}}$ and supplying the oxygen other than that which is air borne. This last mechanism of $\mathrm{NO}_{\mathrm{x}}$ formation is also consistent with the $\mathrm{NO}_{\mathrm{x}}$ emissions increase observable in common rail injection systems. Data are in agreement with researchers that have tested RME on similar engines, but different behaviors can be found in the literature when biodiesels from different feedstock are used in similar engines or when the RME is used in different engine types. In fact, in the premixed combustion phase, an increased HRR with respect to diesel fuel was also found for RME by Tsolakis A. et al. [54]; similarly, Purushothaman K. and Nagarajan G. [55] also evidenced higher HRRs for the orange oil, and Pradeep V. and Sharma R.P. [56] for the Jatropha oil-based biodiesel.

On the contrary, a lower NHRR during the premixed combustion period was found by Sahoo and Das [57] for Jatropha-, Karanja-, and Polanga-based biodiesels, while Sinha and Agarwal found it for a rice bran oil-based biodiesel [58] and by Nwafor and Rice [59] found it for straight rapeseed oil. Qi et al. [60] tested a diesel engine with a neat biodiesel produced from straight soybean oil and found that, at lower engine loads, the net heat release for diesel was slightly lower than for biodiesel, but at higher engine loads, the HRR for diesel fuel was higher. Apart from the biodiesel typology and origin, the engine type may also influence the fuel injection and combustion characteristics of biodiesel. For example, Breda [61] tested RME on a bus diesel engine with an M injection system and found a lower maximum HRR and in-cylinder gas pressure when compared to diesel fuel.

Table 4 summarizes the main results available in the literature, reported here for proper comparisons with the results obtained in this study. All the data refer to engines adopting a PNL injection system at their own rated full load, unless differently indicated.

Table 4. Main characteristics, emissions, and performance of biodiesel-fueled engines in the presented literature.

\begin{tabular}{|c|c|c|c|c|c|}
\hline $\begin{array}{c}\text { Author and } \\
\text { Reference Nr. }\end{array}$ & Type of Biodiesel & $\begin{array}{c}\mathrm{NO}_{\mathrm{x}} \\
\text { Concentration }\end{array}$ & Peak NHRR & $\begin{array}{l}\text { Fuel Injection } \\
\text { System }\end{array}$ & BSFC \\
\hline Tsolakis [54] & B100-rapeseed oil & $+50 \%$ & $+20 \%$ & PLN unmodified & $+15.0 \%$ \\
\hline Purushothaman [55] & B100—orange oil & $+12.5 \%$ & $+33 \%$ & PLN unmodified & $+10.5 \%$ \\
\hline Pradeep [56] & B100-Jatropha & $+8 \%$ & $+2 \%$ & $\begin{array}{l}\text { PLN optimized } \\
\text { for B100 }\end{array}$ & $+12.3 \%$ \\
\hline Sahoo [57] & $\begin{array}{l}\text { B100-Jatropha } \\
\text { B100-Karanja } \\
\text { B100-Polanga }\end{array}$ & $\begin{array}{l}\text { N/A } \\
\text { N/A } \\
\text { N/A }\end{array}$ & $\begin{array}{l}-23 \% \\
-22 \% \\
-25 \%\end{array}$ & PLN unmodified & $\begin{array}{l}\text { N/A } \\
\text { N/A } \\
\text { N/A }\end{array}$ \\
\hline Nwafor [59] & $\begin{array}{l}\text { B100-neat } \\
\text { rapeseed oil }\end{array}$ & & $\sim+5 \%$ & $\begin{array}{l}\text { PLN unmodified- } \\
\text { indirect } \\
\text { injection }\end{array}$ & $+7 \%$ \\
\hline Qi [60] & B100—soybean oil & $-1 \%$ (full load) & $\begin{array}{c}\sim+2 \%(\text { min load }) \\
\sim-5 \%(\text { max load })\end{array}$ & PLN unmodified & $+10 \%$ (full load) \\
\hline Breda [61] & B100—rapeseed oil & $+12.5 \%$ & $-13.3 \%$ & $\begin{array}{c}\text { PLN } \\
\text { unmodified-M } \\
\text { system }\end{array}$ & $+16 \%$ \\
\hline
\end{tabular}

\section{Conclusions}

In this study, a comparative analysis on the use of RME and diesel fuel mixtures on a single-cylinder compression ignition diesel engine has been carried out. The engine presents an in-line mechanical fuel pumping system. This typology of fuel injection technology is still widely adopted in small scale engines and in agricultural machine engines, and, thanks to its intrinsic simplicity, is also useful to better evidence the effects of biodiesel use. In particular, the study focuses on the effect of an alternative fueling on the injection timing, the in-chamber pressure, the heat release rate, and the $\mathrm{NO}_{x}$ emissions. The results of the present article, and the ones available in the literature, regarding the fuel pressure trace in the injection system allow for the conclusion that there is no general 
agreement on the effects of biodiesel on the injection pressure even in the same types of injection systems. This may be due to a noncorrect pressure referencing of the injection pressure traces. In the PLN injection systems, the pressure increase with biodiesel is indeed steeper than with diesel fuel, but the biodiesel pressure just before the injection (i.e., the residual pressure) is lower and, thus, its maximum injection pressure is only slightly greater to the level recorded with the diesel fuel. Unfortunately, even after carefully consulting the literature, it is not always possible to verify which kind of injection pump was used because most of the authors did not record such details.

The fuel injection also affects the combustion heat release and the emissions. No significant variations in the engine torque are found with the variation of the fueling. The injection advance with the RME also anticipates the start of the combustion, and a higher heat release and peak in-cylinder pressure are found on the whole rotational speed range of the engine. As concerns the emissions, the higher nitrogen oxides are often found when adopting biodiesels. In the literature, there are several interpretations of the biodiesel $\mathrm{NO}_{x}$ effect, and the causes of the increase of this pollutant are mainly attributed to the higher content of oxygen in the fuel, the higher combustion pressure and temperature (due to an advance in the SOC), and the higher heat release rate. This study also proposes a modification in the fuel injection advance so to counterbalance the $\mathrm{NO}_{\mathrm{x}}$ effect without affecting the other performance figures of the engine.

Nevertheless, though research on the characterization of biodiesel performance in diesel engines started a long time ago, some issues have not yet been successfully addressed, and further research is still needed to better focus on them. In this respect, this study has tried to supply some considerations and remarks for a specific category of biodiesel-fueled engines with a mechanical injection system that can, however, be extended also to modern engines adopting common rail systems.

Author Contributions: The authors contributed equally to each part of this work. All authors have read and agreed to the published version of the manuscript.

Funding: This research was developed within the "Bio-Tract-Efficiency" ("Experimental investigation on the efficiency of agricultural machines powered with different fuels") internal research project, grant number TN200F, and the "XENERGY" ("Collaboration project with UNIVPM in the field of fluid machines and energy systems") research frame agreement, involving the Libera Università di Bolzano and the Università Politecnica delle Marche.

Institutional Review Board Statement: Not applicable.

Informed Consent Statement: Not applicable.

Data Availability Statement: Not applicable.

Acknowledgments: The authors would like to thank Giorgio Tombari for his help during the experimental phase of this study.

Conflicts of Interest: The authors declare no conflict of interest.

\section{Nomenclature}

$\begin{array}{ll}\text { B100 } & \text { pure biodiesel } \\ \text { BMEP } & \text { brake mean effective pressures } \\ \text { BSFC } & \text { brake-specific fuel consumption } \\ \text { BTDC } & \text { before top dead center } \\ \text { BTE } & \text { brake thermal efficiency } \\ \text { CA } & \text { crank angle (degrees) } \\ \text { CI } & \text { compression-ignited (engine) } \\ \text { CO } & \text { carbon monoxide } \\ \mathrm{CO}_{2} & \text { carbon dioxide } \\ \text { EASAC } & \text { European Academies' Science Advisory Council }\end{array}$




\begin{tabular}{|c|c|}
\hline ECU & electronic control unit \\
\hline EOI & end of injection \\
\hline EU & European Union \\
\hline GHG & greenhouse gases \\
\hline $\mathrm{HC}$ & hydrocarbon \\
\hline HRR & heat release rate \\
\hline $\mathrm{LHV}_{\mathrm{m}}$ & lower heating value on a mass basis \\
\hline ME & methyl esters \\
\hline MSW & municipal solid waste \\
\hline NHRR & net heat release rate \\
\hline $\mathrm{NO}_{\mathrm{x}}$ & nitrogen oxides \\
\hline NREL & National Renewable Energy Laboratory \\
\hline NY & State of New York \\
\hline $\mathrm{OHV}$ & on-head valve \\
\hline PLN & pump-line-nozzle \\
\hline PM & particulate matter \\
\hline RME & rapeseed oil methyl ester \\
\hline SOC & start of combustion \\
\hline SOI & start of ignition \\
\hline USA & United States of America \\
\hline
\end{tabular}

\section{References}

1. Gómez-Marín, N.; Bridgwater, A.V. Mapping bioenergy stakeholders: A systematic and scientometric review of capabilities and expertise in bioenergy research in the United Kingdom. Renew. Sustain. Energy Rev. 2020, 137, 110496. [CrossRef]

2. Dimitriou, I.; Goldingay, H.J.; Bridgwater, A.T. Techno-economic and uncertainty analysis of Biomass to Liquid (BTL) systems for transport fuel production. Renew. Sustain. Energy Rev. 2018, 88, 160-175. [CrossRef]

3. The Royal Society. Sustainable Biofuels: Prospects and Challenges; The Royal Society: London, UK, 2008.

4. Baeyens, J.; Wheeldon, J.; Zhang, H. Editorial. Renew. Energy 2020, 164, 310-312. [CrossRef]

5. Wang, M.; Nie, K.; Cao, H.; Deng, L.; Wang, F.; Tan, T. Biodiesel production by combined fatty acids separation and subsequently enzymatic esterification to improve the low temperature properties. Bioresour. Technol. 2014, 174, 302-305. [CrossRef] [PubMed]

6. Cui, Z.; Huang, S.; Wang, M.; Nie, K.; Fang, Y.; Tan, T. Improving the CFPP property of biodiesel via composition design: An intelligent raw material selection strategy based on different machine learning algorithms. Renew. Energy 2021, 170, 354-363. [CrossRef]

7. Wang, M.; Nie, K.; Yun, F.; Cao, H.; Deng, L.; Wang, F.; Tan, T. Biodiesel with low temperature properties: Enzymatic synthesis of fusel alcohol fatty acid ester in a solvent free system. Renew. Energy 2015, 83, 1020-1025. [CrossRef]

8. Bhuiya, M.M.K.; Rasul, M.G.; Khan, M.M.K.; Ashwath, N.; Azad, A.K. Prospects of 2nd generation biodiesel as a sustainable fuel-Part: 1 selection of feedstocks, oil extraction techniques and conversion technologies. Renew. Sustain. Energy Rev. 2016, 55, 1109-1128. [CrossRef]

9. Panoutsou, C.; Germer, S.; Karka, P.; Papadokostantakis, S.; Kroyan, Y.; Wojcieszyk, M.; Maniatis, K.; Marchand, P.; Landalv, I. Advanced biofuels to decarbonise European transport by 2030: Markets, challenges, and policies that impact their successful market uptake. Energy Strat. Rev. 2021, 34, 100633. [CrossRef]

10. Hoekman, S.K.; Broch, A.; Robbins, C.; Ceniceros, E.; Natarajan, M. Review of biodiesel composition, properties, and specifications. Renew. Sustain. Energy Rev. 2012, 16, 143-169. [CrossRef]

11. Gautam, A.; Agarwal, A. Determination of important biodiesel properties based on fuel temperature correlations for application in a locomotive engine. Fuel 2015, 142, 289-302. [CrossRef]

12. Bietresato, M.; Bolla, A.; Caligiuri, C.; Renzi, M.; Mazzetto, F. The kinematic viscosity of conventional and bio-based fuel blends as a key parameter to indirectly estimate the performance of compression-ignition engines for agricultural purposes. Fuel 2021, 298, 120817. [CrossRef]

13. Bietresato, M.; Bolla, A.; Caligiuri, C.; Renzi, M.; Mazzetto, F. Analysis of cryoscopic behaviour of diesel-biodiesel blends using industrial freezer. In Engineering for Rural Development; Latvia University of Agriculture: Jelgava, Latvia, 2020; pp. 1585-1593.

14. Sorate, K.A.; Bhale, P.V. Biodiesel properties and automotive system compatibility issues. Renew. Sustain. Energy Rev. 2015, 41,777-798. [CrossRef]

15. Demirbas, A. Progress and recent trends in biodiesel fuels. Energy Convers. Manag. 2009, 50, 14-34. [CrossRef]

16. Singh, D.; Sharma, D.; Soni, S.L.; Sharma, S.; Kumar Sharma, P.; Jhalani, A. A review on feedstocks, production processes, and yield for different generations of biodiesel. Fuel 2019, 262, 116553. [CrossRef]

17. Panneerselvam, N.; Murugesan, A.; Vijayakumar, C.; Kumaravel, A.; Subramaniam, D.; Avinash, A. Effects of injection timing on bio-diesel fuelled engine characteristics-An overview. Renew. Sustain. Energy Rev. 2015, 50, 17-31. [CrossRef]

18. Pullen, J.; Saeed, K. Factors affecting biodiesel engine performance and exhaust emissions-Part I: Review. Energy 2014, 72, 1-16. [CrossRef] 
19. Pullen, J.; Saeed, K. Factors affecting biodiesel engine performance and exhaust emissions-Part II: Experimental study. Energy 2014, 72, 17-34. [CrossRef]

20. Bietresato, M.; Friso, D. Durability test on an agricultural tractor engine fuelled with pure biodiesel (B100). Turk. J. Agric. For. 2014, 38, 214-223. [CrossRef]

21. Bietresato, M.; Caligiuri, C.; Bolla, A.; Renzi, M.; Mazzetto, F. Proposal of a Predictive Mixed Experimental- Numerical Approach for Assessing the Performance of Farm Tractor Engines Fuelled with Diesel- Biodiesel-Bioethanol Blends. Energies 2019, 12, 2287. [CrossRef]

22. Mirhashemi, F.S.; Sadrnia, H. NOX emissions of compression ignition engines fueled with various biodiesel blends: A review. J. Energy Inst. 2019, 93, 129-151. [CrossRef]

23. Mani, M.; Nagarajan, G.; Sampath, S. Characterisation and effect of using waste plastic oil and diesel fuel blends in compression ignition engine. Energy 2011, 36, 212-219. [CrossRef]

24. Korakianitis, T.; Namasivayam, A.M.; Crookes, R.J. Diesel and rapeseed methyl ester (RME) pilot fuels for hydrogen and natural gas dual-fuel combustion in compression-ignition engines. Fuel 2011, 90, 2384-2395. [CrossRef]

25. Nabi, M.N.; Rahman, M.M.; Akhter, M.S. Biodiesel from cotton seed oil and its effect on engine performance and exhaust emissions. Appl. Therm. Eng. 2009, 29, 2265-2270. [CrossRef]

26. Shahir, V.K.; Jawahar, C.P.; Suresh, P.R. Comparative study of diesel and biodiesel on CI engine with emphasis to emissions-A review. Renew. Sustain. Energy Rev. 2015, 45, 686-697. [CrossRef]

27. Lapuerta, M.; Armas, O.; Fernández, J.R. Effect of biodiesel fuels on diesel engine emissions. Prog. Energy Combust. Sci. 2008, 34, 198-223. [CrossRef]

28. Xue, J.; Grift, T.E.; Hansen, A.C. Effect of biodiesel on engine performances and emissions. Renew. Sustain. Energy Rev. 2011, 15, 1098-1116. [CrossRef]

29. Varatharajan, K.; Cheralathan, M. Influence of fuel properties and composition on NOx emissions from biodiesel powered diesel engines: A review. Renew. Sustain. Energy Rev. 2012, 16, 3702-3710. [CrossRef]

30. Shameer, P.M.; Ramesh, K. Assessment on the consequences of injection timing and injection pressure on combustion characteristics of sustainable biodiesel fuelled engine. Renew. Sustain. Energy Rev. 2018, 81, 45-61. [CrossRef]

31. Chen, H.; Xie, B.; Ma, J.; Chen, Y. NOx emission of biodiesel compared to diesel: Higher or lower? Appl. Therm. Eng. 2018, 137, 584-593. [CrossRef]

32. Tat, M.E.; Van Gerpen, J.H. Measurement of Biodiesel Speed of Sound and Its Impact on Injection Timing: Final Report; Report 4 in a Series of 6; National Renewable Energy Laboratory: Golden, CO, USA, 2003.

33. Graboski, M.S.; McCormick, R. Combustion of fat and vegetable oil derived fuels in diesel engines. Prog. Energy Combust. Sci. 1998, 24, 125-164. [CrossRef]

34. Lapuerta, M.; Armas, O.; Ballesteros, R.; Fernandez, J. Diesel emissions from biofuels derived from Spanish potential vegetable oils. Fuel 2005, 84, 773-780. [CrossRef]

35. Bietresato, M.; Caligiuri, C.; Renzi, M.; Mazzetto, F. Use of diesel-biodiesel-bioethanol blends in farm tractors: First results obtained with a mixed experimental-numerical approach. Energy Procedia 2019, 158, 965-971. [CrossRef]

36. Bietresato, M.; Calcante, A.; Mazzetto, F. A neural network approach for indirectly estimating farm tractors engine performances. Fuel 2015, 143, 144-154. [CrossRef]

37. Çelikten, I.; Mutlu, E.; Solmaz, H. Variation of performance and emission characteristics of a diesel engine fueled with diesel, rapeseed oil and hazelnut oil methyl ester blends. Renew. Energy 2012, 48, 122-126. [CrossRef]

38. Krahl, J.; Munack, A.; Schröder, O.; Stein, H.; Dutz, M.; Bünger, J. Exhaust Gas Emissions and Health Effects from Biodiesel, Fossil Diesel Fuel, and Swedish Low Sulfur Diesel Fuel MKI. In Proceedings of the American Society of Agricultural and Biological Engineers, Chicago, IL, USA, 28-31 July 2002.

39. Labeckas, G.; Slavinskas, S. The effect of rapeseed oil methyl ester on direct injection Diesel engine performance and exhaust emissions. Energy Convers. Manag. 2006, 47, 1954-1967. [CrossRef]

40. Nwafor, O.M. Emission characteristics of diesel engine operating on rapeseed methyl ester. Renew. Energy 2004, 29, 119-129. [CrossRef]

41. Altın, R.; Çetinkaya, S.; Yücesu, H.S. The potential of using vegetable oil fuels as fuel for diesel engines. Energy Convers. Manag. 2001, 42, 529-538. [CrossRef]

42. Sharon, H.; Karuppasamy, K.; Soban Kumar, D.R.; Sundaresan, A. A test on DI diesel engine fueled with methyl esters of used palm oil. Renew. Energy 2012, 47, 160-166. [CrossRef]

43. Çelikten, İ.; Koca, A.; Ali Arslan, M. Comparison of performance and emissions of diesel fuel, rapeseed and soybean oil methyl esters injected at different pressures. Renew. Energy 2010, 35, 814-820. [CrossRef]

44. Aydın, H.; Bayindir, H. Performance and emission analysis of cottonseed oil methyl ester in a diesel engine. Renew. Energy 2010, 35, 588-592. [CrossRef]

45. Hazar, H. Effects of biodiesel on a low heat loss diesel engine. Renew. Energy 2009, 34, 1533-1537. [CrossRef]

46. Sharma, A.; Murugan, S. Combustion, performance and emission characteristics of a DI diesel engine fuelled with non-petroleum fuel: A study on the role of fuel injection timing. J. Energy Inst. 2015, 88, 364-375. [CrossRef] 
47. Caligiuri, C.; Renzi, M.; Bietresato, M.; Baratieri, M. Experimental investigation on the effects of bioethanol addition in dieselbiodiesel blends on emissions and performances of a micro-cogeneration system. Energy Convers. Manag. 2019, $185,55-65$. [CrossRef]

48. Zhang, Y.; Boehman, A.L. Impact of Biodiesel on NOx Emissions in a Common Rail Direct Injection Diesel Engine. Energy Fuels 2007, 21, 2003-2012. [CrossRef]

49. How, H.G.; Masjuki, H.H.; Kalam, M.A.; Teoh, Y.H. An investigation of the engine performance, emissions and combustion characteristics of coconut biodiesel in a high-pressure common-rail diesel engine. Energy 2014, 69, 749-759. [CrossRef]

50. Ye, P.; Boehman, A.L. An investigation of the impact of injection strategy and biodiesel on engine NOx and particulate matter emissions with a common-rail turbocharged DI diesel engine. Fuel 2012, 97, 476-488. [CrossRef]

51. Agarwal, A.K.; Dhar, A.; Gupta, J.G.; Kim, W.I.; Choi, K.; Lee, C.S.; Park, S. Effect of fuel injection pressure and injection timing of Karanja biodiesel blends on fuel spray, engine performance, emissions and combustion characteristics. Energy Convers. Manag. 2015, 91, 302-314. [CrossRef]

52. Musculus, M.P.B. On the Correlation between NOx Emissions and the Diesel Premixed Burn. SAE Tech. Paper 2004. [CrossRef]

53. Caresana, F. Impact of biodiesel bulk modulus on injection pressure and injection timing. The effect of residual pressure. Fuel 2011, 90, 477-485. [CrossRef]

54. Tsolakis, A.; Megaritis, A.; Wyszynski, M.; Theinnoi, K. Engine performance and emissions of a diesel engine operating on diesel-RME (rapeseed methyl ester) blends with EGR (exhaust gas recirculation). Energy 2007, 32, 2072-2080. [CrossRef]

55. Purushothaman, K.; Nagarajan, G. Performance, emission and combustion characteristics of a compression ignition engine operating on neat orange oil. Renew. Energy 2009, 34, 242-245. [CrossRef]

56. Pradeep, V.; Sharma, R.P. Use of HOT EGR for NOx control in a compression ignition engine fuelled with bio-diesel from Jatropha oil. Renew. Energy 2007, 32, 1136-1154. [CrossRef]

57. Sahoo, P.K.; Das, L.M. Combustion analysis of Jatropha, Karanja and Polanga based biodiesel as fuel in a diesel engine. Fuel 2009, 88, 994-999. [CrossRef]

58. Sinha, S.; Agarwal, A.K. Experimental investigation of the combustion characteristics of a biodiesel (rice-bran oil methyl ester)-fuelled direct-injection transportation diesel engine. Proc. Inst. Mech. Eng. Part D J. Automob. Eng. 2007, 221, 921-932. [CrossRef]

59. Nwafor, O.; Rice, G. Performance of rapeseed oil blends in a diesel engine. Appl. Energy 1996, 54, 345-354. [CrossRef]

60. Qi, D.H.; Geng, L.M.; Chen, H.; Bian, Y.Z.; Liu, J.; Ren, X.C. Combustion and performance evaluation of a diesel engine fueled with biodiesel produced from soybean crude oil. Renew. Energy 2009, 34, 2706-2713. [CrossRef]

61. Kegl, B. Influence of biodiesel on engine combustion and emission characteristics. Appl. Energy 2011, 88, 1803-1812. [CrossRef]

62. Kohler Co. Lombardini Motori by Kohler. Available online: https:// kohlerpower.com/en/engines (accessed on 9 November 2021).

63. AVL. AVL-Development, Testing \& Simulation of Powertrain Systems. Available online: https://www.avl.com/?avlregion= GLOBAL\&groupId=10138\&lang=en_US (accessed on 9 November 2021).

64. PCB Piezotronics Inc. PCB Piezotronics-Sensors to Measure Vibration, Acoustics, Force, Pressure, Load, Strain, Shock, and Torque. Available online: https:/ / www.pcb.com/ (accessed on 9 November 2021).

65. Rakopoulos, C.D.; Antonopoulos, K.A.; Rakopoulos, D.C. Experimental heat release analysis and emissions of a HSDI diesel engine fueled with ethanol-diesel fuel blends. Energy 2007, 32, 1791-1808. [CrossRef] 